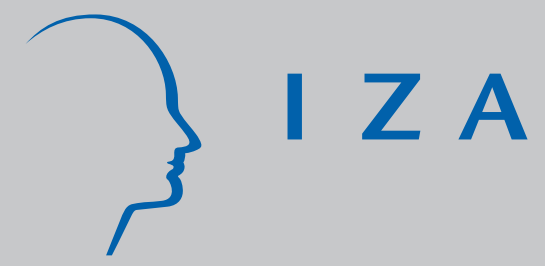

IZA DP No. 6519

Does Corporate Governance Reform Necessarily Boost Firm Performance? Recent Evidence from Russia

Mihails Kuznecovs

Sarmistha Pal

April 2012

Forschungsinstitut zur Zukunft der Arbeit Institute for the Study of Labor 


\title{
Does Corporate Governance Reform Necessarily Boost Firm Performance? Recent Evidence from Russia
}

\author{
Mihails Kuznecovs \\ Brunel University \\ Sarmistha Pal \\ University of Surrey \\ and IZA
}

\section{Discussion Paper No. 6519 \\ April 2012}

IZA

P.O. Box 7240

53072 Bonn

Germany

\author{
Phone: +49-228-3894-0 \\ Fax: +49-228-3894-180 \\ E-mail: iza@iza.org
}

\begin{abstract}
Any opinions expressed here are those of the author(s) and not those of IZA. Research published in this series may include views on policy, but the institute itself takes no institutional policy positions.

The Institute for the Study of Labor (IZA) in Bonn is a local and virtual international research center and a place of communication between science, politics and business. IZA is an independent nonprofit organization supported by Deutsche Post Foundation. The center is associated with the University of Bonn and offers a stimulating research environment through its international network, workshops and conferences, data service, project support, research visits and doctoral program. IZA engages in (i) original and internationally competitive research in all fields of labor economics, (ii) development of policy concepts, and (iii) dissemination of research results and concepts to the interested public.
\end{abstract}

IZA Discussion Papers often represent preliminary work and are circulated to encourage discussion. Citation of such a paper should account for its provisional character. A revised version may be available directly from the author. 


\section{ABSTRACT \\ Does Corporate Governance Reform Necessarily Boost Firm Performance? Recent Evidence from Russia*}

This paper examines whether the introduction of corporate governance (CG) reforms in general and that of transparency and disclosure (T\&D) rules in particular can necessarily boost firm performance. Existing literature suggests that CG reforms can boost performance because it can resolve the conflict of interest between the controlling and the minority owners, especially in societies with highly skewed distribution of ownership. We however argue that the success of CG reform would, in addition, depend on whether the reforms may initiate further conflict, e.g., that between the state and the controlling owners. Using recent data from Russia for 2000-2008, we find that the introduction of corporate governance codes in Russia had limited success to improve indices of firm performance in our sample. We argue that this arises from the predatory behavior of the central and local governments: greater transparency make businesses easy targets for aggressive tax enforcement policy by the central government while the decentralized local governments may increase the bribe price to protect businesses from high central taxes, which may also induce some businesses to go underground, thus harming firm performance.

JEL Classification: $\quad$ G3, K2, P2

Keywords: corporate governance reform, transparency and disclosure rules, conflict between state and the controlling owner, taxation and fiscal decentralisation, firm performance, predatory state, Tobin's Q, Russia

Corresponding author:

Sarmistha Pal

Faculty of Business, Economics and Law

University of Surrey

Guildford GU2 7XH

United Kingdom

E-mail: s.pal@surrey.ac.uk

\footnotetext{
* Mihails Kuznecovs would like to thank Renewable Energy Systems Ltd. for funding this research. We are much grateful to Sergei Guriev not only for helping us locate the Standard \& Poor (S\&P) data on Transparency and Disclosure in Russia, but also constructive feedback on an earlier draft of the paper and S\&P's governance services team for sharing the data with us. We would also like to thank Economics and Finance seminar participants at Brunel University for feedback on an earlier draft of the paper. The usual disclaimer applies.
} 


\section{Introduction}

Existing research suggests that the financial markets are more likely to benefit from external investment if investors enjoy robust legal protection. Both equity and debt investments attract higher prices when corporate governance laws protect the investors against the expropriation by controlling owners. By limiting expropriation by controlling owners, especially when ownership distribution is highly skewed, corporate governance laws may encourage external financing of corporate investment and hence firm performance and growth. The question is whether this perceived link between the introduction of corporate governance (CG) codes and firm performance will necessarily hold always. The present paper tests the validity of this hypothesis by considering large listed corporations in Russia, a country which introduced the corporate governance codes in 2002 (and was made effective from 2004 onwards) amidst a series of other reforms in a radical bid to boost the ailing economy under President Putin.

Russia is a special case in point. Many Russian firms remain family-controlled and highly concentrated leading to large scale expropriation of small investors including minority shareholders and creditors. Consequently, Russian firms often face difficulties securing external funds and are therefore forced to finance most investment internally (Blasi and Shleifer, 1996). Until 2002, Russia had no recognised accounting standards or other official CG mechanism capable of insuring the type of corporate integrity within companies that stimulates investment incentives and financial markets. Low protection of property rights remained a preferred policy of the rich in a country plagued with a very high degree of income inequality. The result was significant undervaluation of Russian firms, which necessitated the introduction of better corporate governance to induce external investors. After years of expropriations of minority shareholders and fierce battles for assets, Russian oligarchs finally began to understand that the only way to sustain the development of its companies is by attracting external funds. When $\mathrm{Mr}$. Putin succeeded Mr. Yeltsin in March 2000, his goal was to reassert Kremlin control over a chaotic, cash-strapped state. First, there was a radical tax reform in 2001 that strengthened tax administration and enforcement by the centralized state (Desai, Dyck and Zingales, 2007). ${ }^{1}$ Next, Russia quickly caught up with the West in adjusting their company and bankruptcy laws to Western standards and introduced the corporate governance codes in 2002. However, law enforcement remains poor (Pistor et al., 2000), primarily due to widespread corruption in courts,

\footnotetext{
${ }^{1}$ The distinctive feature of the tax reforms of 2001 has been the significant emphasis placed on compliance with tax laws and also to introduce changes in administration and enforcement of the laws. In particular, incentives were offered to regional governments to have greater share of local tax revenue in an attempt to prevent them from protecting local tax payers from paying central taxes. Further, tax rate on dividends was raised from $15 \%$ to $30 \%$ while corporate tax rate remained unchanged at 30\% (subsequently it was reduced to a flat rate of 24\%). Thus desperate government attempts to re-establish control on private businesses through aggressive tax enforcement policy resulted in wars between the state and private businesses. ${ }^{1}$
} 
regulatory bodies and law enforcement agencies and also conflict of interest between central and local governments (Treisman, 2000) in a decentralized framework.

The question that we raise here is whether the introduction of $T \& D$ rules in this kind of investment climate can necessarily boost firm performance. Despite privatization, different levels of governments still remain as companies' stakeholders. However, the central government has also a claim on any firm as tax collector and as such there may arise a conflict of interest between the central government as a the stakeholder and that as a tax collector. While the introduction of $\mathrm{T} \& \mathrm{D}$ rules (and also the overall $\mathrm{CG}$ codes) can resolve the conflict of interest between the controlling and minority owners, thus boosting firm performance, it may worsen the conflict between the state as the tax collector and the private controlling owners in Russia. In particular, increasing transparency of businesses may make them easy targets for aggressive tax enforcement policy by the central government and may thus reduce income sheltering or tax evasion. Heinrich (2006) suggests that many oil-and-gas sector firms feared that too much transparency may make them vulnerable to attack from Russia's state agencies. The case of Mikhail Khodrokovsky, founder of the Russian oil and gas giant Yukos, who has been convicted of embezzlement, fraud and tax evasion is particularly noteworthy in this context. This has been a conspicuously aggressive case of state predatory behavior. Further, Treisman (2000) argued that there arose a conflict of interest between the central and local governments in Russia's decentralized economy, which may thwart the central government objective of lowering tax evasion. First in Russia's politically decentralized society, sub-national governments can attract businesses to offer protection against the central government tax collectors, regulators or bankruptcy agency (Treisman, 2000). Second, greater fiscal decentralization in a politically decentralized society may lower the incentive of the regional government to protect businesses against paying taxes, but may in turn increase the bribe price for protection of businesses against central taxes (which in turn may act as additional tax on private businesses). Finally, greater fiscal decentralization may also induce private enterprises to shift part of their output underground, thus adversely affecting performance of the legal entity. Thus the objective of firm value maximization through introduction of $\mathrm{T} \& \mathrm{D}$ rules $^{2}$ may be compromised by various factors which inherently characterizes the Russian political and economic set-up. Accordingly, we argue that the net effect of the introduction of CG reform in Russia could be positive, negative or insignificant (when the positive and negative effects of CG reform outweigh each other). In the

\footnotetext{
${ }^{2}$ Transparency and disclosure (T\&D) is a key aspect of the modern corporate governance mechanism and an important element affecting how attractive a firm appears to potential investors. This is a set of rules, which covers various aspects of corporate practices including a firm's openness about financial and operational information, its ownership structure, and shareholders' rights under the company's governing legal documents and the capabilities of the individual board members and management.
} 
absence of any prior evidence in this respect, we empirically explore the effect of introduction of corporate governance codes in general and that of T\&D rules in particular in Russia.

Our analysis focuses on the largest listed companies in Russia generally for the period $2000-2008^{3}$, the period which witnessed the introduction, implementation and further development of $\mathrm{CG}$ codes along with the reform of tax administration enforcement and also political and fiscal decentralization measures. The companies studied are those which are included by S\&P's T\&D data, covering $80 \%$ of the cumulative market capitalisation of the Russian stock market in 2007 , which were all subject to the newly introduced CG codes. We merge the T\&D data compiled by Standard \& Poor (S\&P) with firm-level accounting data extracted from the OSIRIS database available from Bureau van Dijk.

T\&D data covers six indices on ownership structure, shareholder rights, financial and operational performance, and board and management structure and processes, all of which are important elements that affect a firm's attractiveness to investors. We also use a measure of composite T\&D (obtained by using principal component analysis of six available indices), which allows us to test our central hypothesis that better T\&D improves a firm's performance in Russia. While we do not observe the sample firms' responses to tax reform or alliance with the local governments to evade central taxes, it can be argued that these factors are controlled by the firm and year fixed effects in our analysis. For the purpose of this paper, we experiment with two measures of firm performance as defined by earnings before interest and taxes (EBIT) as a share of total assets and also Tobin's Q (Tobin, 1969); the latter focuses on market valuation of the firm in relation to the cost of capital. The underlying idea is to examine if the effect of the CG reform on firm performance differs according to these two indices of firm performance. Since EBIT is calculated before taxes are imposed, we conjecture that the negative effect of state intervention may be more pronounced on Tobin's Q rather than EBIT share. In the absence of any prior in this respect, we use our data to explore this further. First, we exploit the inter-firm variation in the adoption of $T \& D$ rules (an exogenous policy intervention) to identify the causal effect of introducing the CG code on firm performance; in doing so, we also control for additional firm (e.g., including firm size, leverage, age, and market concentration as measured by the Herfindahl index), sector characteristics, which may otherwise influence firm performance. To this end, we use the OLS firm and year fixed effects estimates that minimize the estimation bias arising from the time-invariant unobserved heterogeneity, e.g., firm response to reform of taxes and also administration and enforcement introduced in 2001 that remained more or less time invariant during 2003-2007. Next we compare the effects of T\&D rules (pertaining to ownership structure, shareholder rights, financial and operational performance, and board and

\footnotetext{
${ }^{3}$ Note that our analysis using S\&P's transparency and disclosure indices only focused on the period 2003-2007 as this data is only available for this period. Please see further discussion in the data section.
} 
management structure and processes) not only on all firms, but also on energy and non-energy sector firms individually in our sample for the period 2003-2007 for which this data is available.

Finally, we assess the impact of the introduction of the overall CG codes made effective from 2004 onwards on firm performance indices in Russia using 2000-2008 data. Note that in this case we are not constrained by 2003-2007 T\&D data available from S\&P and hence we use a slightly larger sample that allows us to extend the end data point to 2008 (the latest year available on Osiris when we initiated this research). Accordingly we replace the T\&D rules indices by a binary indicator of the introduction of corporate governance codes made effective from 2004 onwards. The variable takes a value 1 for all the years from 2004-2008, but zero otherwise. However in order to assess the impact of the CG code over this period, we also need to identify some firms who may be considered as the control group (i.e., those who were not treated by the introduction of Russian CG codes in 2004). Our analysis in this respect exploits the variation in the adoption of CG code by those Russian listed firms who were also listed on international stock exchange. The underlying idea is that in the post-2000 years of rapid Russian recovery and subsequent growth, some Russian listed firms also got listed in international financial markets (mainly in London Stock Exchange) to raise external finance. These firms would often adopt more stringent international CG codes than those listed on Russian stock exchange only. As such, the adoption of international CG codes by these firms would not necessarily coincide with the introduction of Russian CG codes and hence we treat these internationally listed Russian firms as our control group. This allow us to exploit the variation in the adoption of corporate governance codes between domestic and foreign listed companies before and after the effective introduction of Russian CG codes in 2004 with a view to identify a causal effect of introduction of CG codes. The error terms are unlikely to be independent at the firm level. Firms who abide by the $\mathrm{CG}$ codes in time $\mathrm{t}=1$, are also likely to do so in $\mathrm{t}=2$ and so on. Therefore it is important to use the clustered standard errors at the firm level, which assumes that the behavior of firms is not correlated in our analysis.

There is evidence from our analysis that both composite $T \& D$ rules as well as $T \& D$ in financial and operational information significantly boosted the performance of firms, particularly for utility firms in our sample. However the effect of T\&D of any kind remains insignificant for explaining firm performance ${ }^{4}$ among oil-and-gas companies, which holds a particularly prominent place in Russian economy (see further discussion in Section 2). The latter can perhaps be attributed to the conflict of interest between the state and the controlling oligarchs as well as that between the central and the local governments supporting private businesses, thus wiping out improvement in firm value that would have otherwise taken place. Regarding the impact of

\footnotetext{
${ }^{4}$ Among the two measures of firm performance (EBIT and market valuation based Tobin's Q), we find that the effect of T\&D indices on EBIT as a share of total assets is always insignificant; hence, our analysis is essentially based on the results obtained using Tobin's Q.
} 
the introduction of CG codes in 2004, results from the second part of our analysis suggest that internationally listed Russian firms, which require much higher informational disclosure than Russian stock exchange, have significantly higher firm value though the differential effect of CG reform of 2004 for internationally listed firms turns out to be insignificant. As expected, we find that Tobin's Q is a better measure in this respect as the effect remains rather insignificant when we use the EBIT based measure.

Our analysis contributes to a sizeable and growing literature on corporate governance in emerging economies and also the limited literature on tax and corporate governance. In their pioneering article Schleifer and Vishny (1997) highlighted the beneficial influence of good corporate governance laws on firm performance and value. There is evidence from around the world that firms with better corporate governance practices enjoy lower cost of capital (La Porta et al., 1998; Ashbaugh-Skaife et al., 2006; Errunza and Mazumdar, 2001; Ashbaugh et al., 2004), lower credit rate spreads (Yu, 2005) and lower risk (Gompers et al., 2003; Brown and Caylor, 2006). While the earlier literature tends to focus on the ownership and board composition as derived from the agency-cost theory (an ownership and management separation theory explained by Jensen and Meckling, 1976), since the 1990s, the focus has shifted to the legal rules (English common law and French civil law countries) defining creditors' and shareholders' rights. Other studies examine legal enforcement in terms of the rule of law, judicial efficiency and corruption at both country and firm level. Later, Shleifer and Vishny (1997), La Porta et al., (1998) and others found that combining rules relating to ownership and board composition with legal protection for shareholders' rights provides a better understanding of CG practices. More recently, the attention has been shifted to the importance of T\&D rules. Patel and Dallas (2002) has been one of the first studies on $T \& D$, which highlighted that firms with good $T \& D$ have lower costs of equity capital. Gompers, et al. (2003) included T\&D as one of the components of corporate governance rules and found that stronger rights in the US has led to better firm performance. Similarly, Klapper and Love (2002) and Black, et al. (2006) considered T\&D parameters along with other $\mathrm{CG}$ practices. Other studies used $\mathrm{CG}$ indices provided by specialised ranking agencies or constructed their own proxies (see, e.g., Black et. al., 2000; McKinsey \& Company, 2002; and Aggarwal et al., 2007). The general consensus in this literature is that better T\&D tend rules tend to lower the cost of capital, increase firm's performance and provide a better understanding of the firm's business environment. This is because better corporate governance resolves the conflict of interest between the controlling and minority owners. Turning now to the limited literature on corporate governance in Russia, we find three recent studies, namely, Black (2001); Goetzmann, Spiegel and Ukhov (2004) and Black, Love and Rachinsky (2006). All these studies tend to focus on a relatively small sample and none of them particularly focused on the period after the introduction of the corporate governance codes in 
2002. The most recent of these studies, namely that by Black, Love and Rachinsky (2006) analysed overall governance indices over the years 1999-2004. Thus the access to the unique $\mathrm{S} \& \mathrm{P}$ data on $\mathrm{T} \& \mathrm{D}$ rules in the post-reform period allows us to update the effect of corporate governance on firm performance in Russia. We go beyond this literature in that in addition to the conflict of interest between controlling and minority owners, our analysis highlights that introduction of $T \& D$ rules may not be an unmixed blessing, especially if it instigates a conflict of interests between the state and the controlling owners as well as that between the central and the local governments in a decentralized framework. Further, we conduct a formal impact evaluation analysis of the introduction of Russian CG codes in 2004 by exploiting the differential behavior of domestic and internationally listed Russian firms in our sample over 2000-2008. There is suggestion that the international (as opposed to domestic) listing of Russian firms may improve performance of Russian firms though the average impact of the CG reform turns out to be insignificant for the period 2000-2008. Our results also complement the limited literature on tax and corporate governance that argues that a stringent tax enforcement regime can increase the amount outside shareholders will receive, even accounting for increased levels of taxation (see, e.g., Desai, Dyck and Zingales, 2007). Instead we argue that higher taxes and stringent tax enforcement may generate a conflict of interest not only between the controlling owner and the central government, but also between the central and local governments (supporting private businesses), which may counteract the effectiveness of CG reforms (including the T\&D rules).

The paper is developed as follows. Section 2 describes the history of corporate governance in Russia with special reference to the recent corporate governance codes and Section 3 describes the data. Section 4 refers to methodology, while Section 5 presents and analyses the results. The final Section 6 concludes.

\section{Corporate governance in Russia}

Corporate governance (CG) laws/rules have evolved over centuries, often in response to corporate failures or systemic crises. Many think that inadequate and inconsistent regulation of financial markets caused the first global economic crisis of the $21^{\text {st }}$ century. The inadequate availability of accurate information on risk exposure has further highlighted the crucial importance of risk management and disclosure by financial institutions around the globe. As President Obama said in his inaugural address, "this crisis has reminded us that without a watchful eye, the market can spin out of control." Lax oversight allowed corporations to take on excessive risks, and poor disclosure practices left investors unaware of the dangers lurking in their portfolios. 


\subsection{Background}

Russia is a unique case in the context of CG. Barring successful corporate governance systems such as those in the US, Germany or Japan, legal protection of investors in most countries is rather weak, either because the laws are weak or because the courts do not enforce the laws. As a consequence, most firms remain family-controlled and highly concentrated leading to large scale expropriation of small investors including minority shareholders and creditors. This results in serious undervaluation of Russian firms.

The present paper primarily focuses on one aspect of CG mechanism in Russia that deals with $T \& D$ rules. In our case $T \& D$ is the only available, consistent and up-to-date information for firms in our sample. Russia set good T\&D mechanisms in place essentially to protect the rights of the minority shareholders, creditors and other outsiders who do not have first-hand knowledge about the firm and its prospects, against extraction of private benefits by insiders taking advantage of their superior information.

We focus on the period 2000-2008, which has been a period of rapid political and economic changes in Russia when Mr. Putin succeeded Mr. Yeltsin in March 2000. Putin's goal was to reassert Kremlin control over a chaotic, cash-strapped state dominated by big businessmen with a view to replace the oligarchs of Boris Yeltsin's presidency, who hustled their way to wealth in murky post-Soviet privatisations by his own allies. Under President Yeltsin, high tax rates and low levels of tax enforcement encouraged Russian firms to shelter income aggressively. Multiple taxes from different levels of government meant that tax obligations could exceed profits. Company executives were not shy about how this tax burden affected their behavior. As Yukos Oil CEO Khodorkovsky argued, "As long as the tax regime is unjust, I will try to find a way around it." ${ }^{, 5}$ Putin radically strengthened the tax enforcement regime with no change (at least for the first two years) in tax rates and signalled his intentions to crack down on tax evasion by releasing a memorandum with a list of the worst corporate tax offenders (July 28, 2000).

The result was dramatic. Two Yeltsin allies, Boris Berezovsky and Vladimir Gusinsky, fled abroad in 2000 facing fraud charges after clashing with the president. Mikhail Khodorkovsky, owner of oil giant Yukos was arrested three years later on fraud charges and his oil company was hit with a $\$ 28$ bn back tax bill. The Yukos case taught Putin's loyal private businessmen that they held their assets at the Kremlin's pleasure and became involved in politics only at their peril. However, there was still conflict of interest between the central and local governments. In a decentralized set-up, the local goevernments tried to attract private businesses to their municipalities by protecting these businesses against paying central taxes. The Kremlin tried to resolve the conflict of interest between the central and the local governments by

\footnotetext{
${ }^{5}$ This quotation directed from "Oligarch? No, I'm just an oil magnate," Observer, Sunday June 4, 2000
} 
increasing the extent of fiscal decentralization that allowed the local governments to retain $100 \%$ of local revenue raised from personal income taxes. Some municipalities still tried to protect private enterprises from paying central taxes in lieu of high bribe price which is a drag on firm performance. Sometimes these excessive interventions both from the central and local governments induced the private businesses to shift part of their output underground, thus adversely affecting the performance of the legal entity. The result could be a negative or insignificant (when positive and negative effects outweigh each other) effect of introduction of CG codes on firm performance.

\subsection{The 2002 Russian corporate governance codes}

The Russian corporate governance codes, like countless similar documents enacted throughout Europe, claims to embody universal values of good corporate behavior. Russia asked Coudert Brothers, an American law firm, to prepare the international level of its CG with the cooperation of the European Bank for Reconstruction and Development (EBRD), the OECD, the World Bank and the International Finance Corporation.

Before the CG codes were introduced in 2002, several institutions applied a variety of measures to assess the level of CG in Russia. These assessments created useful baseline measures. The Brunswick Warburg investment bank (now as a part of UBS) has rated governance implications since 1999. The Troika Dialog investment house has been assessing selected firms since 2000. Two non-profit organizations, Corporate Law and Governance and the Russian Institute of Directors, have measured CG since 2001 and 2004, respectively. The change in the corporate environment brought out by the introduction of the CG codes in 2002 has been facilitated by a set of policies, which necessitates a firm to be open and willing to disclose financial and management information to the general public (see a detailed explanation of various CG sub-policies in Bollard, 2003). A growing body of literature suggests, however, that Russia's national culture and socio-political environment will also significantly influence how the CG system develops (Kakabadse and Kakabadse, 2001).

The CG code has made some progress since its introduction in 2002. Despite all the drawbacks and lack of a necessary business/political environment, the joint venture between the two energy giants TNK and BP demonstrated Russia's emerging openness to foreign investors. Another positive example of CG implementation within energy firms is the reorganization of the utility holding company RAO UES. GAZPROM, the second largest company in 2003 (by capitalized market value) is seen as having huge business potential. Yukos, the largest energy company has made progress in CG despite (or perhaps leading to) the arrests of several of its executives on charges of tax evasion and economic crimes. Yukos has been releasing financial statements prepared in accordance with US Generally Accepted Accounting Principles (GAAP) 
since 2001 and was audited by the international accounting firm PriceWaterhouseCoopers (PwC) (Yukos website).

Given the availability of the T\&D indices for the period 2003-2007, as compiled by S\&P, we first consider the sample for 2003-2007. In doing so, we not only distinguish between energy and non-energy sector firms, but also distinguish between utility and oil-and-gas sector firms within the energy sector with a view to compare the effect of CG codes across sectors. We also check the robustness of our results in various ways (see further discussion in Section 3). We further extend our analysis to consider the overall effect of the introduction of CG code in 2002 (which was made effective from 2004) on firm performance in our sample for 2000-2008 (which includes years before and after the official introduction of CG codes). In this case, we are also able to account for the differential effect, if any, of the CG reform for internationally listed Russian firms (relative to those listed domestically one). This is motivated by the fact that international listing of Russian firms requires much greater transparency than required by Moscow stock exchange and did not coincide with the introduction of CG reform in 2004.

Some Russian companies moved towards greater T\&D, providing opportunities for foreign investors to acquire an interest in the company and adopting international management practices like international accounting standards, listings on international stock exchanges and thus improved standards of CG. Despite advances by these few CG adopters, however, Russia is still characterized by general lack of transparency in a political environment plagued by centralized state bureaucracy, corruption, and an inefficient judicial system where state machinery often prey on private businesses.

\section{Data}

The data used in this analysis have been obtained primarily from OSIRIS firm-level data for Russian energy companies, which has been widely used in the related academic literature (see e.g., Black, 2001; Klapper and Love, 2002; Goetzmann, Spiegel and Ukhov, 2004; Black, et al., 2006; and Black, Love and Rachinsky, 2006). OSIRIS is a fully integrated public listed company database and analytical information solution produced by Bureau van Dijk, an electronic datapublishing company. In this respect, we consider the listed Russian firms between 2000 and 2008, which has been a period of rapid economic recovery and subsequent growth under the leadership of President Putin. OSIRIS data was then merged with the firm-level T\&D data obtained from S\&P (see Appendix 1 for further details on the construction of these indices).

We apply GICS 4-digit code to classify firms in our sample. As we focus on energy industry, GICS allowed us to identify 9 main energy subsectors within the energy industry. We have selected utilities and oil and gas producers as the two largest ones consisting $64 \%$ of overall energy sector. The two largest energy sectors consist of 23 companies. The remaining energy 
sector companies are labelled as 'other energy' sector (which consists of 13 companies). Appendix 2 provides some summary statistics for the selected sectors and subsectors. Given that S\&P's T\&D indices focus on the largest energy sector firms, we considered the 36 largest firms in 2007. While 181 Russian energy firms are available in the OSIRIS, the 36 within S\&P's database are the largest ones. Further, we distinguish energy sector firms from leading nonenergy sectors, which include firms operating in telecommunications, metallurgy, banking, food, consumer and retails and IT engineering.

Russia's stock market is dominated by the natural resources sectors, which comprises about two-thirds of the market (Lazareva, et al., 2007). Russia has the largest proven natural gas reserves in the world (1,688 trillion cubic feet) and the seventh-largest proven oil reserves $(60.0$ billion to 74.4 billion barrels) (BP review, 2007). Europe depends on Russian energy - Russia provides $33.5 \%$ of the oil consumed in the EU and $42 \%$ of its gas usage (Erixon, 2008). The importance of the energy sector in our study can further be highlighted by two following observations. First of all, the Russian energy companies are significant because of how much they contribute to the economy. When Russia began implementing its CG mechanism, five energy giants, namely, Yukos, Gazprom, Lukoil, Surgutneftegaz and Sibneft, cumulatively represented 56\% of the value of all the stocks listed on the Russian Stock Market: USD 106,408 million out of USD 189,029 millions in 2003 (Expert RA, 2004). Foreign investors often considered stock in Russian energy firms to be a key holding in their international portfolio. Further, a comparison of total sales by companies in these two sectors between 2003 and 2007 clearly highlights the importance of energy sector firms in Russia. Percentage of total sales by energy industry varies between $82 \%-85 \%$ during this period; in other words, only about $15 \%$ $18 \%$ of total sales pertain to the non-energy sector of the country.

Firm-level balance sheet data from OSIRIS pertains to profit and loss accounts and cash flow statements for all existing firms. Although we use the comprehensive firm-level database to analyse effects within the energy sector, the consistency of information from OSIRIS and S\&P allows us to be confident of the descriptive statistics and regression analyses we produce.

\subsection{Transparency \& Disclosure Indices}

We obtained a number of different $T \& D$ indices from $S \& P$ covering various aspects of corporate financial behavior. This allows us to assess the predictive power of different measures of T\&D. It is important to choose the most acceptable $T \& D$ measures. Unlike much of the existing literature, we have access to S\&P's T\&D indices consistently constructed for the 80 largest listed Russian companies with the most liquid stocks (80\% of cumulative market capitalisation of Russian stock market, in 2007) over the period 2003-2007 (S\&P's reports, 2003-2007). 
A clarification is in order before we begin: while there are more than 300 public companies in Russia (who are all subject to the new CG codes), we focus on the largest companies covered by S\&P; this sample may not be representative of all Russian companies. Because the larger companies tend to be more transparent than the smaller ones, our sampling method is likely to generate an upward bias in assessing transparency of the entire population of public Russian companies. In contrast, since the companies included in this survey account for about $80 \%$ of the cumulative capitalization of the Russian stock market, they represent the major part of the Russian economy in terms of assets and operations. Subject to these clarifications, we considered the following T\&D indices ${ }^{6}$ :

- T\&D financial and operational information

- T\&D ownership structure and shareholders rights

- T\&D board and management structure

We used the T\&D overall score, which measures general implementation of the CG code. As defined by S\&P, T\&D's 'financial \& operational' index measures openness and availability of accounting data, employment standards, consistency with regulations, explanation and description of the firm and its market position, etc. The T\&D's 'ownership' index demonstrates the availability of data on the ownership structure. The T\&D's 'board \& shareholders' index shows the disclosure of the management structure. S\&P measures T\&D score in percentages with a maximum $100 \%$; a higher score means better T\&D within the company. The same T\&D indices were used by Black, Love and Rachinsky (2006) though their sample covered a period up to 2005 only.

Using this available data, the present research first investigates the possible effect of T\&D rules on firm's value (firm performance) for top listed companies in Russia. Our research not only covered the energy sector, but was also extended to non-energy sectors firms covering telecommunications, retail, communications, and real estate among others. Our results clearly show that the energy industry generally underperformed relative to the non-energy related sectors (see Figure 1 and Table 1). Despite its lower performance initially, the T\&D overall index for the energy sector corporations subsequently moved up so that they are now on are in line with the other industries.

\footnotetext{
${ }^{6} \mathrm{~S} \& \mathrm{P}$ applied two criteria to select the companies in the study: size and liquidity. As a rule, the liquidity of stocks positively depends on the size of the company, but there are exceptions, especially in cases of minor free-float. Each T\&D index is based on about 30 survey questions for each of the sections: T\&D financial and operational information, T\&D ownership structure and shareholders rights, T\&D board and management structure. These questionnaires were circulated to the top Russian firms from various industries like telecommunications, energy, manufacturing, and advertising. S\&P analysis accounts for information included in the three major sources of public information: annual reports, Web-based disclosures, and public regulatory reporting. S\&P views corporate transparency as an important factor affecting a firm's attractiveness to investors and an important element of corporate governance. The study includes around 80 largest Russian stock companies with the most liquid assets. The companies included in the survey account for about $90 \%$ of the cumulative capitalization of the Russian stock and market and they represent the major part of the Russian economy in terms of assets and operations.
} 
Next we considered the trend in T\&D indices over the sample years as shown in Figure 1. It follows that the energy sector's T\&D overall index increased from $40 \%$ in the first two years after the CG policy implementation to around $55 \%$ in 2007 , which moves into line with the average level for the country as a whole.

Although the non-energy companies started at a higher level of T\&D than the energy companies in 2003, by 2007 they were at the same level as energy companies, indicating that overall transparency increased faster for firms in the energy sector. Similar observations are noted when we consider individual T\&D indices: the progress was faster in the energy sector. Black, Love and Rachinsky (2006) made similar observations for the period 1999-2004. Figure 1 summarises the change in various $T \& D$ measures and also the composite $T \& D$ measure over 20023-2007, which highlights a growing trend of firm-level transparency on all accounts in our sample.

\subsection{Treatment and control groups - internationally vs. domestic listed firms}

Although all sample firms were listed in the stock exchange, it is important for us to find out if some firms were listed in any international stock exchange; the latter may sometimes be labeled as cross-listing as these firms were not only listed in Russian stock exchange, but also in some other foreign stock exchanges. This is particularly important for the post-2000 period, which was the period of economic recovery that subsequently gave rise to rapid economic growth in Russia. During this period many of the largest Russian firms went into listing on foreign stock exchanges (often in London stock exchange). While we can extract information from OSIRIS as to whether a firm was listed in the international stock exchange in the latest year of the survey, unfortunately, this information has not been available for other years during 2000 and 2007. However, given that listing is relatively time invariant, we use this 2008 information to assess if internationally listed Russian firms behave differently from other domestically listed firms (see further discussion in Sections 4.2 and 5.2) because they were subject to more stringent international CG codes. In other words, we consider domestically listed Russian firms as the treatment group as they were primary guided by the Russian CG codes introduced in 2002 and made effective from 2004 onwards. In contrast, internationally listed Russian firms constitute the control groups as they are guided by different international rules.

\section{Methodology}

Our first objective has been to identify the causal effect of introduction of T\&D rules on firm performance in Russia. To do so, we first explored the role of each T\&D index on firm value for the post-reform period 2003-2007, using panel data fixed effects models. Given the shortcoming of fixed effects models to control for unobserved time-varying heterogeneity, if any, we next 
consider the effect of introduction of corporate governance codes in Russia in 2002 (which was made effective from 2004), with a view to identify the effect of CG code in general, if possible. Next, we assess the impact of the introduction of CG codes in 2004 by exploiting the variation in the adoption of corporate governance codes between domestic and foreign listed companies with a view to identify a causal effect of CG before and after the introduction of CG code.

\subsection{OLS fixed effects estimates of firm value, 2003-2007}

To start with, we employ a panel-data fixed-effects model using Ordinary Least Squares (OLS). Our sample is a balanced panel data arranged for a group of firms observed over the years 20032007. Choice of the sample period is guided by the fact that the T\&D indices are available only for 2003-2007. The measure of firm performance is Tobin's Q. After controlling for other possible covariates, namely, firms size, age, Herfindahl index, performance of $\mathrm{i}$-th firm in year $\mathrm{t}$ is given by:

$\mathrm{Q}_{\mathrm{it}}=\beta_{\mathrm{T} \& \mathrm{D}} \mathrm{T} \& \mathrm{D}_{\mathrm{it}}+\beta_{\mathrm{S}}$ Size $_{\mathrm{it}}+\beta_{\mathrm{A}} \mathrm{Age}_{\mathrm{it}}+\beta_{\mathrm{H}}$ Herfindahl $_{\mathrm{it}}+\beta_{\mathrm{L}}$ Leverage $_{\mathrm{it}}+\alpha_{\mathrm{i}}+\theta_{\mathrm{t}}+\mathrm{v}_{\mathrm{it}}$ Eq. (1)

where, $\mathrm{t}=2003-2007$,

$\alpha_{\mathrm{i}}=$ firm-specific unobserved factor

$\theta_{\mathrm{t}}=$ Year specific unobserved factor

$\mathrm{V}_{\mathrm{it}}=$ firm (i) and year (t) specific error term (independently and identically distributed).

The advantage of using fixed-effects model is that it allows us to minimize estimation bias arising from any possible time-invariant unobserved heterogeneity. The parameter $\alpha_{i}$ accounts for the firm-specific time-invariant unobserved factors, e.g., effects of corporate taxes and also tax enforcement as well as other government policies affecting the sample firms, inclusion of which is likely to minimise the potential estimation bias arising from firm-specific unobserved heterogeneity. Further, in order to minimize the bias generated by reverse causality, we have lagged all explanatory variables by one period. We use a fixed effects panel data model to estimate Eq. (1). Further we cluster all standard errors at the firm-level to minimize any estimation bias arising from interdependence of errors over time for each firm.

Tobin's $\mathrm{Q}$ is a widely used measure of firm performance in the literature (e.g., Mueller and Reardon 1993; Blanchard et al., 1993; Denis and McConnell, 2003 and La Porta et al., 2002). In our study, we constructed two alternative measures of Tobin's Q:

- firm market capitalisation divided by total assets 
- firm market capitalisation plus total debt divided by total assets ${ }^{7}$

Table 1 shows the descriptive statistics for all the regression variables in our sample. Note that the average value of Tobin's Q varies between 0.87 and 2.27 , depending on the particular definition of the variable and also the sector in which they were operating. Researchers have suggested that the largest Russian companies find themselves overvalued, since the market value of a company is greater than the recorded assets (e.g., Tobin and Brainard, 1977). In our investigation, utility firms have the smallest performance index, around 1.00, which still points towards overvaluation.

In order to identify the effect of T\&D on Tobin's Q, we controlled for additional firmlevel characteristics, which are likely to influence firm performance. These control variables include firm age, Herfindahl index of market concentration, company size (as the natural logarithm of total assets) and leverage (the ratio of total liabilities to total assets). Choice of these variables is guided by the literature, e.g., Franks and Mayer (2002), Rajan and Zingales (1995), and Booth, et al. (2001), de Haas and Peters (2004), Cole (2008) and Driffield and Pal (2010).

We measured market concentration using the Herfindahl index, named after its original proponent Herfindahl (1950). Essentially, the Herfindahl index measures how concentrated the industry is; many competitors in a sector result in lower concentration while fewer competitors increases the level of concentration. As a rule of thumb, a Herfindahl index below 0.10 signals low concentration or an unconcentrated market, while a Herfindahl index above 0.18 signals high concentration. An index falling between 0.10 and 0.18 indicates that the industry is moderately concentrated ${ }^{8}$. Table 1 shows that the average Herfindahl index is high for all the sectors considered in our analysis, implying a monopolistic market environment in Russia.

We also included how long the firm had been in existence. In general, Table 1 demonstrates that the average age of all the firms in our study is 20 years. The most recently established firms in the oil-and-gas production sector average 7 years old; the oldest companies in the utilities sector average 30 years old. The average ratio of total liabilities to total assets is about 0.45 . It follows that, compared to the utilities; firms in the oil-and-gas subsector are not only larger on average, but also more leveraged.

\footnotetext{
${ }^{7}$ We also tried other profitability parameters such as return on assets and earnings before interest and taxes divided by total assets, but were unable to find any significant evidence with these alternative measures.

8 In our analysis we have multiplied Herfindahl index by 100 in order to standardize the variable. U.S. Department of Justice and the Federal Trade Commission in the 'Horizontal Merger Guidelines' apply Herfindahl indexation up to $100^{2}$ or in $10^{\prime} 000$ s. (http://www.justice.gov/atr/public/guidelines/hmg.htm\#N_17_).
} 


\section{Difference-in-Difference estimates of firm value}

Although we do not have access to any T\&D indices for the period before 2003, (T\&D information is available only for 2003-2007), we generate a binary variable indicating introduction of corporate governance rules in the country. Recalling that Russia introduced CG mechanism in 2002, the first reporting year under these new rules was 2003, for which the financial reports did not become available until 2004. Accordingly we constructed a dummy variable CG2004 that takes a value 1 for year 2004 and beyond and zero for the years before 2004. The rationale for doing this is to exploit the exogenous introduction of CG reform as an instrument for $\mathrm{T} \& \mathrm{D}$ rules in our sample. Impact assessment also necessitated us to identify a control group of firms who were not necessarily affected by the introduction of CG codes in 2004. As a result, we are also able to consider the larger sample of 2000-2008 in this case. Given that many Russian firms got internationally listed in post-2000 years, a period of rapid economic recovery and subsequent growth in Russia, we treat these firms as our control (untreated by the CG codes) group. Accordingly, we create a second binary variable LI that takes a value 1 if a sample firms was listed during 2000-2008 and 0 otherwise. Internationally listed Russian firms were subject to more stringent $\mathrm{CG}$ rules and as such we can exploit this variation across domestically and internationally listed firms to identify the differential effect of CG reform, if any, on internationally listed firms (this is captured by the inclusion of the interaction between CG2004 and LI). Accordingly, we specify a Difference-in-Difference (DID) model determining Tobin's Q of the i-th firm as follows:

$$
\mathrm{Q}_{\mathrm{i}}=\beta_{\mathrm{CG}} \mathrm{CG} 2004+\beta_{\mathrm{LI}} \mathrm{LI}+\beta_{\mathrm{CGLI}} \mathrm{CG} 2004 * \mathrm{LI}+\beta_{\mathrm{X}} \mathrm{X}+\mathrm{u}_{\mathrm{i}}
$$

The DID method has become popular in empirical economics since its genesis in Ashenfelter (1978) and is probably the most widely used method for impact evaluation. In effect, DID is largely a two-period panel data model with fixed effects, assumed for the treatment status and time period (before/after the introduction of reform).

As before, we included other covariates $\mathrm{X}$ which includes firm size, age, Herfindahl index and leverage to identify the causal effect of T\&D rules on Tobin's Q. Further, we include sector control as we pool all industries together. ${ }^{9}$ The sector control would capture the effects of the unobserved sector level factors including taxes, tax-enforcement and/or any shocks. Since we do not have time-varying information on internally listed Russian firms, we use pooled estimates. However note that all estimates are clustered around firms with a view to minimize any estimation bias arising from inter-dependence of firm specific errors over time.

\footnotetext{
${ }^{9} \mathrm{We}$ do not produce industry specific estimates in this case as the sample size is significantly reduced, if we do so.
} 
Ceteris paribus, the estimated coefficient of the period dummy CG2004 would highlight the effect of introduction of corporate governance codes on firm value for all sample firms. Note however that the CG2004 dummy incorporates the overall effect of all corporate governance reform and not just the effect of the T\&D rules which we considered in Section 4.1. The estimated coefficient of LI (internationally listed Russian firms) would however highlight the effect of international listing LI on Tobin's $Q$ in our sample. The variable of particular interest to us is $\beta_{\text {CGLI }}$, which is the interaction term between LI and CG2004. The estimated coefficient of the interaction term would allow us to identify the differential effect of the introduction of CG code on internationally listed firms, if any. This is the crucial coefficient which determines the mean impact of the introduction of the CG code in our sample. In order to check the robustness of our estimates, we also consider the estimates of share of EBIT in an alternative specification.

\section{Results and discussion}

This section presents and analyses the estimates of Eq. (1) for our sample. Section 6.1 discusses the estimates of Eq. (1) for the utilities and oil-and-gas subsectors within energy sector and also compares the estimates for the overall energy sector firms with other non-energy sector firms. Section 6.2 presents and analyses the estimates of Eq. (2) for the period 2000-2008.

\subsection{FE-OLS estimates of firm value, 2003-2007}

Table 2 summarises the FE-OLS estimates of Tobin's Q as in Eq. (1) using the composite T\&D index. Table 3 shows the FE-OLS estimates of Tobin's Q using the T\&D financial and operational information measure. The estimates using other T\&D indices were not significant in determining Tobin's Q in our sample. We do not show them, but will make them available on request. Table 4 finally shows the FE-OLS estimates of the alternative firm performance index, namely, EBIT as a share of total assets in our sample, for comparison with Tobin's Q estimates.

In general, estimates from Table 2 are rather similar to those in Table 3. We show estimates for two alternative measures of Tobin's Q as explained in the data section. For each of the chosen Tobin's Q measures, the estimated coefficient of the particular T\&D index is not only significant for the all sector taken together, but also for the energy industry (utilities and oil and gas sector) pooled together. After controlling for all other factors, the significant positive effect of $T \& D$ rules appears when considering composite $T \& D$ and $T \& D$ financial \& operational information availability (although the level of significance varies somewhat among different subsamples). These findings support John and Senbet (1998), Errunza and Mazumdar (2001), Roberts (2004), and Yeoh (2007), who argued that recognised accounting and corporate integrity within companies can stimulate investment incentives and, in the end, financial markets, thus explaining higher firm value. If, however, we compare the estimates between the two major 
energy sub-sectors, utilities and oil-and-gas producers, the T\&D effect is significant only for utilities. It thus appears that the estimate for the overall energy sector (in column 3 of Table 2) has been driven by the utilities (see columns 10 of Table 2 and columns 5 and 10 of Table 3 ).

A possible explanation for the lack of significance of T\&D in the oil-and-gas sector may arise from the conflict of interest between the controlling owner and the state as well as that between the central and state governments. As indicated earlier, this is a sector dominated by the five energy giants comprising of about $56 \%$ of total market capital of Moscow Stock Exchange, Evidently these energy firms are significantly bigger than other non-energy sector firms (see Table 1) and as such may be subject to greater predatory behavior of the state, thus giving rise to a conflict of interest between the controlling owners and the state, which may counteract the purpose of introducing T\&D rules. Accordingly, the energy giants may have greater stakes from the prying eyes of state agencies, especially when new corporate governance code requires them to be transparent. This is because greater transparency may make them more vulnerable to higher taxes by the state agencies (the recent high profile case of Mikhail Khodorkovsky of Yukos is a pointer to this argument). Thus the conflict of interest between controlling owner and the state may harm firm value in the oil and gas sector in various ways; it may be attributable to the high bribe price paid by these large companies to shelter high revenue and/or transferring part of the output underground to avoid tax intervention by the government (Triesman). While the positive T\&D effect for all firms in our sample tends to be in line with the existing literature about Russian corporations (see e.g., Black, 2001; Goetzmann, Spiegel and Ukhov, 2004; Black, Love and Rachinsky, 2006), we believe that the identification of the potential negative effect of introduction of $T \& D$ rules, which may render total effect to be insignificant as in the case of the Russian oil-and-gas sector is a novel contribution of our analysis and we attribute this to the predatory behaviour of the state.

Among other results, our study shows that a firm's size (measured by total assets) and leverage (calculated as the ratio of liabilities to assets) both tend to lower firm performance irrespective of the Tobin's Q measure chosen. In contrast, firm performance is significantly better for older firms. There is also a significant negative relationship between the Herfindahl index of market concentration and firm performance for firms in the oil-and-gas production sector and for all non-energy industries. The negative effect in non-energy firms is almost three times as large compared to the oil-and-gas companies.

It is also interesting to compare the Tobin's Q estimates with the corresponding EBIT as a share of total assets estimates. Note that Table 4 only shows the estimates for all sectors combined where columns (1)-(4) highlights the estimates using different components of T\&D indices. After controlling for all other factors, we find that all these estimated coefficients of various $T \& D$ indices are negative, the coefficient is only statistically significant for $T \& D$ 
ownership. In other words, ceteris paribus, there is evidence from our sample that greater transparency with respect to ownership information generates a negative impact on EBIT based firm performance measure, even before taxes are deducted. Again, this result highlights potential negative effect of the conflict of interest between the centralized state and the controlling owner and also that between the central and the local governments.

Note however that the introduction of T\&D rules is only one aspect of overall CG reform in Russia and hence we next consider the effect of the overall CG reform on firm performance in Russia. In doing so, we also consider the larger sample of listed firms available from Osiris in section 6.2. In a sense, this additional exercise would allow us to test the robustness of our results pertaining to introduction of $\mathrm{T} \& \mathrm{D}$ rules.

\subsection{DID estimates of firm performance 2000-2008}

In this section, we make use of the impact evaluation literature (i.e., difference-in-difference or in short DID estimates) to assess the effect of CG reform on selected indices of firm performance in Russia. Since information on whether a firm is listed on international stock exchange is generally time-invariant, we are assuming that the 2008 information on whether a Russian firm is listed on international stock exchange) is also pertinent for all the years between 2000 and 2008 . Accordingly, we shall, in this subsection, consider the estimates of Eq. (2) for same Russian listed firms as in section 6.1 but for the larger period 2000-2008. The DID estimates of various firm performance measures (Tobin's Q and EBIT as a share of total assets) are summarized in Table 5. Columns (1) and (2) show the estimates for Tobin's Q defined as the ratio of firm's market capital to total assets while columns (3) and (4) show those for a second measure of Tobin's Q (ratio of market capital plus debt to total assets). Finally, column (5) and (6) show the DID estimates of EBIT as a share of total assets. While columns (1), (3) and (5) do not control for any other explanatory variables, estimates for the complete specifications that include other control variables are respectively shown in columns (2), (4) and (6) for these three alternative measures of firm performance. In this respect, our discussion is couched in terms of the complete specifications shown in columns (2), (4) and (6) that minimize the omitted variable bias. In particular, our analysis focuses on the estimates for CG2004, LI (a binary variable indicating if a firm is listed in international stock exchange) and their interaction term. As before, all estimates are clustered at the firm level to minimize any further estimation bias.

First we focus on the estimates using two alternative indices of Tobin's Q. Introduction of corporate governance codes is associated with significantly higher values of Tobin's Q (irrespective of the definition) in columns (1) and (3) when we do not control for any other explanatory variables. However, it loses its significance in columns (2) and (4) as we include other explanatory variables. In contrast, internationally listed companies tend to have 
significantly higher Tobin's Q in columns (2) and (4). Since by controlling for all other factors influencing firm value, we minimize the omitted variable bias, we prefer the estimates shown in columns (2) and (4) for these two alternative measures. There is thus evidence from our analysis that, ceteris paribus, internationally (relative to domestically) listed Russian firms tend to have significantly higher firm value in our sample. However, the interaction term measuring the mean impact of the CG reform turns out to be statistically insignificant; in other words, there is no evidence from our sample that internationally listed Russian firms enjoyed higher firm value in the post CG reform period in our sample, after holding other factors constant. Note however that none of these central variables are statistically significant when we focus on EBIT as a share of total assets. Thus there is no evidence that the reform boosted firm performance measured by EBIT as a share of total assets.

To summarise, these DID estimates again confirm the limited effectiveness of the introduction of CG codes in Russia, even when we pool all sectors together. Clearly the effect of the $\mathrm{CG}$ reform on firm performance has been even weaker when we consider the EBIT-based measure of performance rather than Tobin's Q. Given that there is evidence of increase in T\&D indices in our sample (see discussion in Section 3.1), we argue that the introduction of the CG reform since 2004 has not been associated with a statistically significant increase in firm value; the latter can be attributed to the conflict of interest between the controlling owner and the state, which intervenes in private businesses through excessive taxes. It can also be attributed to the conflict of interest between the central and local governments in a decentralized set up which may not only impose a high bribe price for helping private businesses to evade central taxes, but may also drive parts of some private businesses underground in a desperate attempt to avoid paying taxes.

\section{Concluding comments}

Using recent firm-level panel data from Russia, this paper investigates whether an introduction of CG codes would necessarily boost firm performance.

We argue that an understanding of corporate governance in Russia requires an identification of the conflict of interests not only between the controlling and minority owners, but also that between the controlling owners and the centralized state as well as that between the central and local governments in a decentralized set-up. State may not only act as the stakeholder of a company, but also has the tax-setting power. While introduction of CG codes may increase firm value by resolving the conflict of interest between the controlling and minority owners in Russia's highly concentrated ownership structure, introduction of tax reform, stringent tax enforcement and decentralisation may counteract the $\mathrm{CG}$ reforms. So the net effect of 
introduction of CG codes may be positive, negative or no effect at all, when the positive and negative effects exactly outweigh each other.

Unlike many existing studies, our analysis has been facilitated by the recent availability of S\&P data on T\&D for the top listed firms in Russia for the period 2003-2007. We were able not only to consider Russian energy firms, but also to compare the specific cases of Russia's non-energy sector companies. Even within the energy sector, we have been able to compare the cases of the utilities and oil-and-gas subsectors for their obvious contributions (significance) to the Russian economy. There is evidence from our fixed effects panel data estimates that the various $T \& D$ rules has been met with only limited success to boost firm value especially for the all important oil and gas sector. This is because CG reforms initiated a conflict of interest between the large energy giants and the centralized state while the tax reform and decentralization generates the conflict of interest between the central and local governments. The impact of the introduction of CG code is even weaker when we examine the impact of introduction of corporate governance codes (which include broader measures over and above T\&D rules) of 2002 (which was made effective from 2004 onwards) on various indices of firm performance, after exploiting the variation in the impact of the code between domestic and internationally listed Russian firms in our sample for 2000-2008: while CG dummy remains insignificant in determining firm value, ceteris paribus, internationally listed Russian firms tend to have significantly higher market value. There is however no significant differential positive effect of CG reform on firm value among internationally listed firms so that the average impact effect turns out to be insignificant. We argue that these results support our central hypothesis and also complement Desai, Dyck and Zingales (2007) who argued that a stringent tax enforcement can increase the amount outside shareholders will receive, even accounting for increased levels of taxation. We argue that higher taxes, stringent tax enforcement and fiscal decentralisation may generate a conflict of interest between the controlling owner and the state and also that between the central and local governments, which may counteract the effectiveness of other CG reforms. Although this is a case study of Russia, the results from this study has wider implications beyond the country, especially, in other central and eastern European countries as well as the countries from the community of independent states (CIS), where state control on private businesses often remains firm even after radical privatisation programmes.

This conflict of interest between Russian corporate oligarchs and the state has induced many Russian oligarchs to invest abroad. The latter, in turn, has gradually been paving the way for increasing inward foreign investment in Russia, as highlighted by the recent BP deal in the oil-and-gas sector of the country. It would be interesting to see whether and how inward foreign multinational investment can resolve the conflict of interest between the state and the controlling private owners, thus contributing to sustained improvement in firm value in Russia. 


\section{References}

Aggarwal, R., Isil, E., Stulz, R., and Williamson, R., 2007. Differences in governance practice between u.s. and foreign firms: measurement, causes, and consequences.Working Paper, Ohio State University.

Ashbaugh, H., Collins, D. W.,La Fond, R., 2004. Corporate governance and the cost of equity capital. Working paper, University of Wisconsin-Madison

Ashbaugh-Skaife, H., Collins, D.W., La Fond, R., 2006. The effects of corporate governance on firms' credit ratings. Journal of Accounting and Economics 42,203-243.

Ashenfelter, O. 1978.

Black, B.S., Coudert Brothers, Shin \& Kim, International Development Law Institute, 2000. Corporate governance in Korea at the millennium: enhancing international competitiveness. Final report and legal reform recommendations, consulting services for corporate governance reform in Korea.

Black, B., 2001. The corporate governance behavior and market value of Russian firms. Emerging Markets Review 2, 89-108.

Black, B.S., Love, I., Rachinsky, A., 2006. Corporate governance and firms' market values: time series evidence from Russia. Emerging Markets Review 7, 361-379.

Blasi, J.R., Shleifer, A., 1996. Corporate governance in Russia: an initial look. In: Frydman, Gray, and Rapaczynski (editors), Corporate governance in Central Europe and Russia: insiders and the state. Central European University, Budapest.

Bollard, A., 2003. Corporate governance in the financial sector. (Governor of the Reserve Bank of New Zealand, to The Annual Meeting of the Institute of Directors in New Zealand, Christchurch, 7 April 2003).

Visited: $3^{\text {rd }}$ January 2011, http://www.rbnz.govt.nz/speeches/0132484.html

Booth, L., Aivazian, V., Demirguc-Kunt, A., Maksimovic, V., 2001. Capital structure in developing countries. The Journal of Finance 56, 87-130.

British Petroleum (BP) Statistical Review, 2007. World proved reserves of oil and natural gas, most recent estimates., U.S. Department of Energy, Energy Information Administration, Ibid.:6 -22. Accessed at www.eia.doe.gov/emeu/international/reserves.html (August 20, 2007).

Brown, L., Caylor, M., 2006. Corporate governance and firm performance. Journal of

Accounting and Public Policy, 25 issue 4, 409-434.

Cole, R.A., 2008. What do we know about the capital structure of privately held firms? Evidence from the surveys of small business finances. SBA Government, SBAHQ-06-Q-0013.

de Haas, R.T.A., Peters, H.M.M., 2004. Firms' dynamic adjustment to target capital structures in transition economies. WO Research Memoranda (discontinued) 761, Netherlands Central Bank, Research Department.

Desai, M., A. Dyck and L. Zingales. 2007. Theft and Taxes. Journal of Financial Economics, 84, 591-623

Driffield, N.L., Pal, S., 2010. Evolution of capital structure in East Asia - corporate inertia or endeavours? Journal of the Royal Statistical Society (series A) 173 part 1, 1-29.

Erixon, F., 2008. Europe's energy dependency and Russia's commercial assertiveness. European Centre for International Political Economy No. 07, ISSN 1653-8994.

Errunza, V.R., Mazumdar, S.C., 2001. Privatization: a theoretical framework. Journal of International Financial Markets, Institutions and Money 11, issues 3-4, 339-362.

Expert RA, 2004. Entrepreneurial Ethics and Corporate Governance in Russia: Investor Perceptions and Business Reality.

Financial Times. 2006.' Back in business - how Putin's allies are turning Russia into a corporate state', June 19.

Franks, J., Mayer, C., 2002.Governance as a source of managerial discipline. Research series 20020512, National Bank of Belgium.

Goetzmann, W.N., Spiegel, M.I., Ukhov, A., 2004. Modelling and measuring Russian corporate governance: the case of Russian preferred and common shares (English version). Yale School of Management Working Papers, Yale School of Management.

Gompers, P., Ishii, J. and Metrick, A. 2003. Corporate governance and equity prices. Quarterly Journal of Economics 118, issue 1, 107-155.

Heinrich, A., 2006. International implications of increased state control over the Russian oil and gas sector. Eastern European Day 2006, "Russian Challenges - Between Freedom and Energy", Fribourg, Switzerland, 23 June 2006. 
Herfindahl, O.C., 1950. Concentration in the U.S Steel industry. Unpublished doctoral dissertation, Columbia University.

Jensen, M.C., Meckling, W.H., 1976. Theory of the firm: managerial behaviour, agency costs and ownership structure. Journal of Financial Economics, vol. 3(4), pp. 305-360.

John, K., Senbet, L., 1998.Corporate governance and board effectiveness. Journal of Banking and Finance 22, No.4, 371-403.

Kakabadse, A., Kakabadse, N., 2001. The geopolitics of governance: the impact of contrasting philosophies. Basingstoke, Palgrave.

Klapper L., Love, I., 2002. Corporate governance, investor protection, and performance in emerging markets. Policy Research Working Paper No. 2818, World Bank, Washington, DC.

La Porta, R., Lopez-De-Silanes, F., Shleifer, A., Vishny R., 2002. Investor protection and corporate valuation. The Journal of Finance 57, No. 3, 1147-1170.

La Porta, R., Lopez-de-Silanes, F., Shleifer, A., Vishny, R., 1998. Law and finance. Journal of Political Economy 106, pp. 1113-1155.

Lazareva, O., Rachinsky, A., Stepanov, S., 2007. A survey of corporate governance in Russia. CEFIR/ NES Working Paper, No. 103.

McKinsey \& Company, 2002. Global investor opinion survey: key findings. New York.

Mueller, D.C., Reardon, E.A., 1993. Rates of return on corporate investment. Southern Economic Journal 60, No. 2, 430-453.

Patel, S.A., Dallas, G., 2002. Transparency and disclosure: overview of methodology and study results - United States, Standard \& Poor's.

Pistor, K., Raiser, M., Gelfer, S., 2000. Law and finance in transition economies. The Economics of Transition 8, 325-368.

Rajan, R., Zingales, L., 1995. What do we know about capital structure? Some evidence from international data. Journal of Finance 50, 1421-1460.

Roberts, J., 2004. The modern firm: organizational design for performance and growth. Oxford University Press.

Shleifer, A., Vishny, R.W., 1997. A Survey of corporate governance. The Journal of Finance 52, No. 2, 737-783.

Standard \& Poor's, 2003. Russian Transparency and Disclosure survey 2003: positive changes in practices of Russian companies. Standard \& Poor's Governance Services.

Standard \& Poor's, 2004. Russian Transparency and Disclosure survey 2004: positive trend continues despite political obstacles. Standard \& Poor's Governance Services.

Standard \& Poor's, 2005. Russian Transparency and Disclosure survey 2005: continuing progress in transparency, but mainly among weaker disclosers. Standard \& Poor's Governance Services.

Standard \& Poor's, 2006. Transparency and Disclosure by Russian companies 2006: modest progress amid the IPO deal. Standard \& Poor's Governance Services.

Standard \& Poor's, 2007. Transparency and Disclosure by Russian companies 2007: high turnover in the top 10. Standard \& Poor's Governance Services.

Tobin, J., 1969. A general equilibrium approach to monetary theory. Journal of Money Credit and Banking 1, No. 1, 15-29.

Tobin, J., Brainard, W.C., 1977. Asset markets and the cost of capital. Economic Progress, Private Values and Public Policy.

Treisman, D. 2000. 'Decentralization, Tax Evasion and the Underground Economy: A Model with Evidence from Russia', mimeo, University of California Los Angeles.

Yeoh, P., 2007. Corporate governance models: is there a right one for transition economies in Central and Eastern Europe? Managerial Law 49 issue 3, 57-75.

Yu, F., 2005. Accounting transparency and the term structure of credit spreads. Journal of Financial Economics 75, 53-84. 
Table 1: Means and standard deviations of selected T\&D indexes, firm performance and additional variables, 2000-2008

\begin{tabular}{|c|c|c|c|c|c|c|c|c|c|c|c|c|c|c|c|}
\hline \multirow{2}{*}{ Variable } & \multicolumn{3}{|c|}{ All industries } & \multicolumn{3}{|c|}{ Non-energy sector } & \multicolumn{3}{|c|}{ Energy sector } & \multicolumn{3}{|c|}{$\begin{array}{l}\text { Oil-and-gas } \\
\text { producers }\end{array}$} & \multicolumn{3}{|c|}{ Utilities } \\
\hline & Obs & Mean & $\begin{array}{l}\text { Std. } \\
\text { Dev. }\end{array}$ & Obs & Mean & $\begin{array}{l}\text { Std. } \\
\text { Dev. }\end{array}$ & Obs & Mean & $\begin{array}{l}\text { Std. } \\
\text { Dev. }\end{array}$ & Obs & Mean & $\begin{array}{l}\text { Std. } \\
\text { Dev. }\end{array}$ & Obs & Mean & $\begin{array}{l}\text { Std. } \\
\text { Dev. }\end{array}$ \\
\hline \multicolumn{16}{|c|}{ Performance/Firm value proxies } \\
\hline Tobin's Q \#1 ver. & 267 & 1.17 & 1.35 & 134 & 1.31 & 1.73 & 133 & 1.03 & 0.78 & 58 & 1.11 & 0.75 & 39 & 0.87 & 0.85 \\
\hline Tobin's Q \#2 ver. & 263 & 1.61 & 1.32 & 130 & 1.87 & 1.66 & 133 & 1.36 & 0.79 & 58 & 1.44 & 0.75 & 39 & 1.15 & 0.87 \\
\hline \multicolumn{16}{|l|}{ T\&D scores } \\
\hline $\mathrm{T} \& \mathrm{D}$ overall & 202 & 0.52 & 0.16 & 94 & 0.54 & 0.17 & 108 & 0.50 & 0.15 & 40 & 0.50 & 0.17 & 34 & 0.46 & 0.12 \\
\hline T\&D financial \& operational & 202 & 0.54 & 0.18 & 94 & 0.56 & 0.18 & 108 & 0.52 & 0.18 & 40 & 0.53 & 0.20 & 34 & 0.44 & 0.15 \\
\hline T\&D ownership & 202 & 0.52 & 0.18 & 94 & 0.55 & 0.20 & 108 & 0.49 & 0.16 & 40 & 0.47 & 0.19 & 34 & 0.47 & 0.12 \\
\hline T\&D board \& shareholders & 202 & 0.48 & 0.16 & 94 & 0.50 & 0.18 & 108 & 0.46 & 0.14 & 40 & 0.44 & 0.16 & 34 & 0.47 & 0.13 \\
\hline Stock market listing & 630 & 0.81 & 0.39 & 306 & 0.76 & 0.42 & 324 & 0.86 & 0.35 & 117 & 0.69 & 0.46 & 90 & 1.00 & 0.00 \\
\hline Foreign listing & 630 & 0.19 & 0.39 & 306 & 0.24 & 0.42 & 324 & 0.14 & 0.35 & 117 & 0.31 & 0.46 & 90 & 0.00 & 0.00 \\
\hline $\begin{array}{l}\text { Firm concentration } \\
\text { Herfindalh index }\end{array}$ & 630 & 92.77 & 25.74 & 306 & 89.51 & 59.23 & 324 & 108.86 & 23.44 & 117 & 144.70 & 19.69 & 90 & 372.83 & 418.22 \\
\hline Firm size, leverage, age & & & & & & & & & & & & & & & \\
\hline Ln of total assets & 451 & 14.39 & 1.71 & 232 & 13.89 & 1.61 & 219 & 14.91 & 1.67 & 83 & 15.69 & 1.83 & 55 & 14.25 & 1.37 \\
\hline $\begin{array}{l}\text { Liabilities to assets } \\
\text { Firm age }\end{array}$ & $\begin{array}{l}442 \\
522\end{array}$ & $\begin{array}{c}0.45 \\
19.58\end{array}$ & $\begin{array}{c}0.23 \\
26.60\end{array}$ & $\begin{array}{l}223 \\
279\end{array}$ & $\begin{array}{c}0.53 \\
18.85\end{array}$ & $\begin{array}{c}0.22 \\
24.22\end{array}$ & $\begin{array}{l}219 \\
243\end{array}$ & $\begin{array}{c}0.37 \\
20.41\end{array}$ & $\begin{array}{c}0.22 \\
29.12\end{array}$ & $\begin{array}{l}83 \\
99\end{array}$ & $\begin{array}{l}0.36 \\
6.69\end{array}$ & $\begin{array}{l}0.19 \\
4.60\end{array}$ & $\begin{array}{l}55 \\
45\end{array}$ & $\begin{array}{c}0.33 \\
30.02\end{array}$ & $\begin{array}{c}0.20 \\
44.23\end{array}$ \\
\hline
\end{tabular}

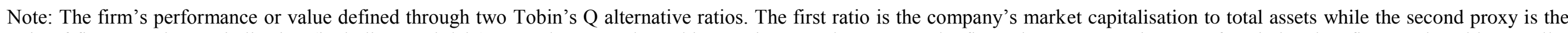

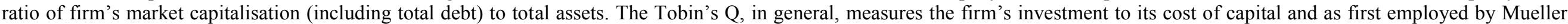

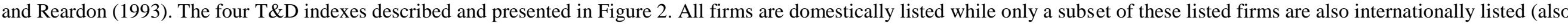

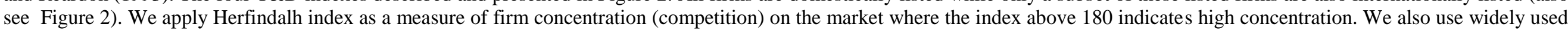

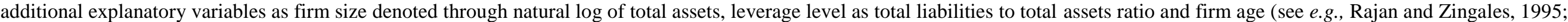
De Haas and Peters, 2004; Cole, 2008; Driffield and Pal, 2010). 
Table 2: FE-OLS estimates of Tobin's Q: T\&D composite index, 2003-2007

\begin{tabular}{|c|c|c|c|c|c|c|c|c|c|c|}
\hline & \multicolumn{5}{|c|}{ A. Tobin's Q \#1 version } & \multicolumn{5}{|c|}{ B. Tobin's Q \#2 version } \\
\hline & $\begin{array}{c}\text { All } \\
\text { industries }\end{array}$ & $\begin{array}{c}\text { Non-energy } \\
\text { industries }\end{array}$ & $\begin{array}{l}\text { Energy } \\
\text { industry }\end{array}$ & $\begin{array}{l}\text { Oil-and- } \\
\text { gas } \\
\text { production }\end{array}$ & $\begin{array}{l}\text { Utilities } \\
\text { sector }\end{array}$ & $\begin{array}{c}\text { All } \\
\text { industries }\end{array}$ & $\begin{array}{l}\text { Non-energy } \\
\text { industries }\end{array}$ & $\begin{array}{l}\text { Energy } \\
\text { industry }\end{array}$ & $\begin{array}{l}\text { Oil-and- } \\
\text { gas } \\
\text { production }\end{array}$ & $\begin{array}{c}\text { Utilities } \\
\text { sector }\end{array}$ \\
\hline T\&D overall & $1.323 *$ & 1.086 & $1.328 *$ & 0.771 & 1.274 & $1.366 *$ & 1.129 & $1.371 *$ & 0.817 & $1.317 *$ \\
\hline & $(0.792)$ & $(0.771)$ & $(0.795)$ & $(0.790)$ & $(0.788)$ & $(0.785)$ & $(0.764)$ & $(0.788)$ & $(0.783)$ & $(0.780)$ \\
\hline Herfindalh index & 0.0202 & $-0.0752 * *$ & 0.0127 & $-0.0247 * *$ & 0.00266 & 0.0204 & $-0.0744 * *$ & 0.0127 & $-0.0245^{* *}$ & 0.00271 \\
\hline & $(0.015)$ & $(0.031)$ & $(0.010)$ & $(0.010)$ & $(0.002)$ & $(0.014)$ & $(0.030)$ & $(0.010)$ & $(0.010)$ & $(0.002)$ \\
\hline Total assets & $\begin{array}{c}\mathbf{- 0 . 6 7 4 * *} \\
(0.274)\end{array}$ & $\begin{array}{c}\mathbf{- 0 . 5 8 6 * *} \\
(0.265)\end{array}$ & $\begin{array}{c}\mathbf{- 0 . 6 6 8 * *} \\
(0.275)\end{array}$ & $\begin{array}{l}-\mathbf{- 0 . 5 2 6 *} \\
(0.267)\end{array}$ & $\begin{array}{c}\mathbf{- 0 . 6 8 3 * *} \\
(0.274)\end{array}$ & $\begin{array}{c}\mathbf{- 0 . 5 5 6 * *} \\
(0.272)\end{array}$ & $\begin{array}{l}-\mathbf{- 0 . 4 6 7 *} \\
(0.262)\end{array}$ & $\begin{array}{c}\mathbf{- 0 . 5 5 0} * * \\
(0.272)\end{array}$ & $\begin{array}{l}-0.408 \\
(0.265)\end{array}$ & $\begin{array}{c}-\mathbf{- 0 . 5 6 5} * * \\
(0.272)\end{array}$ \\
\hline $\begin{array}{l}\text { Liabilities to assets, } \\
\text { lag }\end{array}$ & $\begin{array}{l}-0.612 \\
(0.809)\end{array}$ & $\begin{array}{l}-0.556 \\
(0.788)\end{array}$ & $\begin{array}{c}-0.612 \\
(0.811)\end{array}$ & $\begin{array}{l}-0.821 \\
(0.786)\end{array}$ & $\begin{array}{l}-0.674 \\
(0.804)\end{array}$ & $\begin{array}{l}-0.563 \\
(0.801)\end{array}$ & $\begin{array}{l}-0.509 \\
(0.781)\end{array}$ & $\begin{array}{l}-0.562 \\
(0.804)\end{array}$ & $\begin{array}{l}-0.771 \\
(0.779)\end{array}$ & $\begin{array}{l}-0.624 \\
(0.796)\end{array}$ \\
\hline Firm age & $\begin{array}{c}\mathbf{0 . 2 6 5}^{* * * *} \\
(0.097)\end{array}$ & $\begin{array}{l}-0.162 \\
(0.145)\end{array}$ & $\begin{array}{c}\mathbf{0 . 2 4 2} * * * * \\
(0.089)\end{array}$ & $\begin{array}{l}-0.189 \\
(0.157)\end{array}$ & $\begin{array}{c}\mathbf{0 . 3 6 2} * * \\
(0.148)\end{array}$ & $\begin{array}{c}\mathbf{0 . 2 6 0}^{* * * *} \\
(0.096)\end{array}$ & $\begin{array}{l}-0.164 \\
(0.144)\end{array}$ & $\begin{array}{c}\mathbf{0 . 2 3 7} * * * * \\
(0.088)\end{array}$ & $\begin{array}{l}-0.192 \\
(0.156)\end{array}$ & $\begin{array}{c}\mathbf{0 . 3 5 9} * * \\
(0.147)\end{array}$ \\
\hline Constant & $\begin{array}{c}3.529 \\
(3.802)\end{array}$ & $\begin{array}{c}\mathbf{1 6 . 8 6}^{* * * *} \\
(5.217)\end{array}$ & $\begin{array}{c}4.259 \\
(3.615)\end{array}$ & $\begin{array}{c}\mathbf{1 6 . 4 6}^{* * * *} \\
(5.122)\end{array}$ & $\begin{array}{c}1.608 \\
(4.558)\end{array}$ & $\begin{array}{c}2.27 \\
(3.764)\end{array}$ & $\begin{array}{c}15.52 * * * \\
(5.173)\end{array}$ & $\begin{array}{c}3.009 \\
(3.578)\end{array}$ & $\begin{array}{c}15.17 * * * \\
(5.078)\end{array}$ & $\begin{array}{c}0.286 \\
(4.515)\end{array}$ \\
\hline Sector control & Yes & No & No & No & No & Yes & No & No & No & No \\
\hline Firm FE & Yes & Yes & Yes & Yes & Yes & Yes & Yes & Yes & Yes & Yes \\
\hline Year FE & Yes & Yes & Yes & Yes & Yes & Yes & Yes & Yes & Yes & Yes \\
\hline Observations & 137 & 137 & 137 & 137 & 137 & 136 & 136 & 136 & 136 & 136 \\
\hline R-squared & 0.15 & 0.191 & 0.147 & 0.189 & 0.153 & 0.15 & 0.189 & 0.146 & 0.189 & 0.153 \\
\hline $\begin{array}{l}\text { Number of } \\
\text { companies }\end{array}$ & 52 & 52 & 52 & 52 & 52 & 51 & 51 & 51 & 51 & 51 \\
\hline Prob $>F$ & 0.0210 & 0.0041 & 0.0240 & 0.0043 & 0.0190 & 0.0213 & 0.0043 & 0.0244 & 0.0044 & 0.0188 \\
\hline
\end{tabular}

Note: Legends $(*)$ to the right of the coefficients represent the significance intervals $(* * * \mathrm{p}<0.01, * * \mathrm{p}<0.05, * \mathrm{p}<0.1)$ and robust standard errors are shown in parentheses.

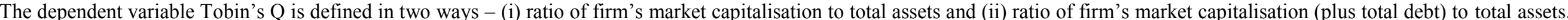

Definitions of explanatory variables are presented in Table 1 . The regressions results are derived using OLS with firm and year fixed effects estimates. 
Table 3: FE-OLS estimates of Tobin's Q: T\&D financial \& operational reports, 2003-2007

\begin{tabular}{|c|c|c|c|c|c|c|c|c|c|c|}
\hline & \multicolumn{5}{|c|}{ A. Tobin's Q \#1 version } & \multicolumn{5}{|c|}{ B. Tobin's Q \#2 version } \\
\hline & $\begin{array}{c}\text { All } \\
\text { industries }\end{array}$ & $\begin{array}{c}\text { Non- } \\
\text { energy } \\
\text { industries }\end{array}$ & $\begin{array}{l}\text { Energy } \\
\text { industry }\end{array}$ & $\begin{array}{l}\text { Oil-and- } \\
\text { gas } \\
\text { production }\end{array}$ & $\begin{array}{l}\text { Utilities } \\
\text { sector }\end{array}$ & $\begin{array}{c}\text { All } \\
\text { industries }\end{array}$ & $\begin{array}{c}\text { Non- } \\
\text { energy } \\
\text { industries }\end{array}$ & $\begin{array}{l}\text { Energy } \\
\text { industry }\end{array}$ & $\begin{array}{l}\text { Oil-and- } \\
\text { gas } \\
\text { production }\end{array}$ & $\begin{array}{c}\text { Utilities } \\
\text { sector }\end{array}$ \\
\hline T\&D financial \& & $1.176 * *$ & $1.022 *$ & $1.189 * *$ & 0.82 & $1.126 *$ & $1.212 * *$ & $1.059 *$ & $1.224 * *$ & 0.859 & $1.161 * *$ \\
\hline operational & $(0.575)$ & $(0.564)$ & $(0.576)$ & $(0.581)$ & $(0.575)$ & $(0.569)$ & $(0.558)$ & $(0.570)$ & $(0.575)$ & $(0.569)$ \\
\hline Herfindalh index & 0.0184 & $-0.0724 * *$ & 0.0116 & $-\mathbf{0 . 0 2 3 3} * *$ & 0.00235 & 0.0185 & $-0.0714 * *$ & 0.0116 & $-0.0231 * *$ & 0.00238 \\
\hline & $(0.014)$ & $(0.031)$ & $(0.010)$ & $(0.010)$ & $(0.002)$ & $(0.014)$ & $(0.030)$ & $(0.010)$ & $(0.010)$ & $(0.002)$ \\
\hline Total assets & $\begin{array}{c}\mathbf{- 0 . 6 7 0} * * \\
(0.270)\end{array}$ & $\begin{array}{c}\mathbf{- 0 . 5 9 1} * * \\
(0.261)\end{array}$ & $\begin{array}{c}-\mathbf{- 0 . 6 6 6 * *} * \\
(0.270)\end{array}$ & $\begin{array}{c}-\mathbf{- 0 . 5 4 0} * * \\
(0.264)\end{array}$ & $\begin{array}{c}-\mathbf{- 0 . 6 7 6} * * \\
(0.270)\end{array}$ & $\begin{array}{c}\mathbf{- 0 . 5 5 1} * * \\
(0.267)\end{array}$ & $\begin{array}{c}-\mathbf{- 0 . 4 7 3} * \\
(0.259)\end{array}$ & $\begin{array}{c}-\mathbf{0 . 5 4 7} * * \\
(0.268)\end{array}$ & $\begin{array}{l}-0.421 \\
(0.261)\end{array}$ & $\begin{array}{c}\mathbf{- 0 . 5 5 7} * * \\
(0.267)\end{array}$ \\
\hline Liabilities to assets, & $\begin{array}{l}-0.735 \\
(0.799)\end{array}$ & $\begin{array}{l}-0.656 \\
(0.780)\end{array}$ & $\begin{array}{l}-0.734 \\
(0.801)\end{array}$ & $\begin{array}{l}-0.884 \\
(0.778)\end{array}$ & $\begin{array}{l}-0.788 \\
(0.795)\end{array}$ & $\begin{array}{l}-0.689 \\
(0791)\end{array}$ & -0.612 & $\begin{array}{l}-0.688 \\
(0.793)\end{array}$ & -0.838 & $\begin{array}{l}-0.742 \\
(0.787)\end{array}$ \\
\hline Firm age & $\begin{array}{c}\mathbf{0 . 2 6 0} * * * * \\
(0.096)\end{array}$ & $\begin{array}{l}-0.148 \\
(0.144)\end{array}$ & $\mathbf{0 . 2 3 9} * * *$ & $\begin{array}{l}-0.169 \\
0157)\end{array}$ & $\mathbf{0 . 3 4 2} * *$ & $\mathbf{0 . 2 5 5} * * *$ & -0.149 & $0.234 * * *$ & -0.171 & 0.339*** \\
\hline Constant & $\begin{array}{c}(0.090) \\
3.82 \\
(3.779)\end{array}$ & $\begin{array}{c}16.53 * * * \\
(5.168)\end{array}$ & $\begin{array}{c}(0.000) \\
4.477 \\
(3.587)\end{array}$ & $\begin{array}{c}16.00 * * * \\
(5.109)\end{array}$ & $\begin{array}{c}(0.148) \\
2.199 \\
(4.550)\end{array}$ & $\begin{array}{c}(0.095) \\
2.568 \\
(3.738)\end{array}$ & $\begin{array}{c}15.18 * * * \\
(5.122)\end{array}$ & $\begin{array}{c}(0.087) \\
3.232 \\
(3.548)\end{array}$ & $\begin{array}{c}14.69 * * * \\
(5.062)\end{array}$ & $\begin{array}{c}(0.140) \\
0.894 \\
(4.505)\end{array}$ \\
\hline Sector control & Yes & No & No & No & No & Yes & No & No & No & No \\
\hline Firm FE & Yes & Yes & Yes & Yes & Yes & Yes & Yes & Yes & Yes & Yes \\
\hline Year FE & Yes & Yes & Yes & Yes & Yes & Yes & Yes & Yes & Yes & Yes \\
\hline Observations & 137 & 137 & 137 & 137 & 137 & 136 & 136 & 136 & 136 & 136 \\
\hline R-squared & 0.164 & 0.203 & 0.162 & 0.2 & 0.165 & 0.165 & 0.203 & 0.162 & 0.2 & 0.166 \\
\hline $\begin{array}{l}\text { Number of } \\
\text { companies }\end{array}$ & 52 & 52 & 52 & 52 & 52 & 51 & 51 & 51 & 51 & 51 \\
\hline Prob $>F$ & 0.0121 & 0.0024 & 0.0134 & 0.0028 & 0.0116 & 0.0117 & 0.0024 & 0.0131 & 0.0027 & 0.0111 \\
\hline
\end{tabular}

Note: Legends $(*)$ to the right of the coefficients represent the significance intervals $(* * * p<0.01, * * p<0.05, * p<0.1)$ and robust standard errors are shown in parentheses.

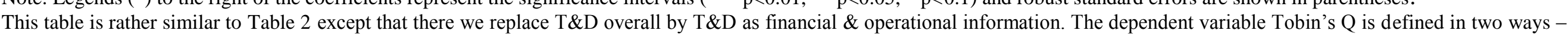

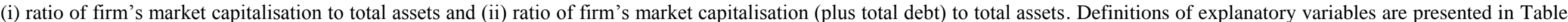

1. The regressions results are derived using OLS with firm and year fixed effects estimates. 
Table 4: FE-OLS estimates of EBIT to Total assets ratio: T\&D index reports, 2003-2007

\begin{tabular}{l|c|c|c|c}
\hline \multirow{4}{*}{} & \multicolumn{4}{|c}{ Dependent: EBIT to total assets ratio } \\
\cline { 2 - 5 } & T\&D & $\begin{array}{c}\text { T\&D } \\
\text { financial \& } \\
\text { overall }\end{array}$ & $\begin{array}{c}\text { T\&D } \\
\text { ownership }\end{array}$ & $\begin{array}{c}\text { T\&D } \\
\text { board \& } \\
\text { management }\end{array}$ \\
\hline \multirow{4}{*}{ T\&D indexes } & & & & \\
& -0.0758 & -0.0364 & $\mathbf{- 0 . 1 3 7 * *}$ & -0.0554 \\
Herfindalh index & $(0.059)$ & $(0.043)$ & $(0.061)$ & $(0.053)$ \\
& -0.000504 & -0.000404 & -0.000843 & -0.000571 \\
Total assets & $(0.001)$ & $(0.001)$ & $(0.001)$ & $(0.001)$ \\
& $\mathbf{- . 0 5 0 2 * *}$ & $\mathbf{- 0 . 0 5 3 5 * *}$ & $\mathbf{- 0 . 0 4 4 5 * *}$ & $\mathbf{- 0 . 0 5 3 4 * *}$ \\
Liabilities to assets, lag & $(0.021)$ & $(0.021)$ & $(0.021)$ & $(0.021)$ \\
Firm age & -0.0466 & -0.0345 & -0.0755 & -0.0364 \\
& $(0.063)$ & $(0.062)$ & $(0.064)$ & $(0.062)$ \\
Constant & $\mathbf{0 . 0 2 0 0 * *}$ & $\mathbf{0 . 0 1 9 7 * *}$ & $\mathbf{0 . 0 1 9 7 * *}$ & $\mathbf{0 . 0 1 8 9 * *}$ \\
& $(0.008)$ & $(0.008)$ & $(0.008)$ & $(0.008)$ \\
Firm FE & $\mathbf{0 . 5 3 0 *}$ & $\mathbf{0 . 5 5 2 *}$ & $\mathbf{0 . 5 2 1} *$ & $\mathbf{0 . 5 8 6 * *}$ \\
Year FE & $(0.292)$ & $(0.294)$ & $(0.284)$ & $(0.288)$ \\
Observations & Yes & Yes & Yes & Yes \\
R-squared & Yes & Yes & Yes & Yes \\
Number of companies & 158.00 & 158.00 & 158.00 & 158.00 \\
Prob>F & 0.168 & 0.16 & 0.196 & 0.163 \\
\hline & 56.00 & 56.00 & 56.00 & 56.00 \\
& 0.0028 & 0.0042 & 0.0006 & 0.0036 \\
\hline
\end{tabular}

Note: Legends $(*)$ to the right of the coefficients represent the significance intervals $(* * * \mathrm{p}<0.01, * * \mathrm{p}<0.05$, $* \mathrm{p}<0.1)$ and robust standard errors are shown in parentheses.

Definitions of explanatory variables are presented in Table 1. The regressions results are derived using OLS with firm and year fixed effects. 
Table 5: DID estimates of Firm Performance Measures 2000-2008

\begin{tabular}{|c|c|c|c|c|c|c|}
\hline \multirow{2}{*}{$\begin{array}{c}\text { Dependent } \\
\text { Tobin's Q } \\
\text { For All industries }\end{array}$} & \multicolumn{2}{|c|}{ A. Tobin's Q \#1 version } & \multicolumn{2}{|c|}{ B. Tobin's Q \#2 version } & \multicolumn{2}{|c|}{ C. EBIT/TA } \\
\hline & $\begin{array}{l}\mathrm{CG}, \text { Listed } \\
\text { Internationally } \\
\text { firms }\end{array}$ & $\begin{array}{c}\text { with } \\
\text { control } \\
\text { variables }\end{array}$ & $\begin{array}{l}\mathrm{CG}, \text { Listed } \\
\text { Internationally } \\
\text { firms }\end{array}$ & $\begin{array}{c}\text { with } \\
\text { control } \\
\text { variables }\end{array}$ & $\begin{array}{c}\text { CG, Listed } \\
\text { Internationally } \\
\text { firms }\end{array}$ & $\begin{array}{c}\text { with } \\
\text { control } \\
\text { variables }\end{array}$ \\
\hline CG2004 & $\begin{array}{c}\mathbf{0 . 3 2 9} * * * * \\
(0.124)\end{array}$ & $\begin{array}{l}0.0925 \\
(0.138)\end{array}$ & $\begin{array}{c}\mathbf{0 . 4 0 2}^{* * * *} \\
(0.126)\end{array}$ & $\begin{array}{c}0.124 \\
(0.137)\end{array}$ & $\begin{array}{c}-0.00156 \\
(0.015)\end{array}$ & $\begin{array}{c}-0.0266 \\
(0.020)\end{array}$ \\
\hline Listed Internationally & 0.362 & $0.897 * *$ & 0.233 & $0.838 * *$ & -0.0424 & -0.0464 \\
\hline dummy & $(0.417)$ & $(0.354)$ & $(0.414)$ & $(0.369)$ & $(0.031)$ & $(0.032)$ \\
\hline CG*Listed & 0.695 & -0.32 & 0.659 & -0.277 & 0.0279 & 0.0409 \\
\hline Internationally dummy & $(0.475)$ & $(0.374)$ & $(0.461)$ & $(0.374)$ & $(0.034)$ & $(0.028)$ \\
\hline Sector control & Yes & Yes & Yes & Yes & Yes & Yes \\
\hline Intercept & Yes & Yes & Yes & Yes & Yes & Yes \\
\hline Other control & No & Yes & No & Yes & No & Yes \\
\hline Observations & 267 & 255 & 263 & 253 & 450 & 389 \\
\hline R-squared & 0.09 & 0.28 & 0.11 & 0.26 & 0.02 & 0.03 \\
\hline
\end{tabular}

Note: Legends $(*)$ to the right of the coefficients represent the significance intervals $(* * * \mathrm{p}<0.01, * * \mathrm{p}<0.05$, * $\mathrm{p}<0.1$ ) and robust standard errors are shown in parentheses.

The dependent variable s Tobin's $Q$ defined as the ratio of firm's market value to total assets. The alternative Tobin's Q is defined as firm's market value (plus total debt) as a share of total assets. Explanatory variables definitions are presented in Table 1. Unlike Tables 2 or 3, we now include LI, which is a dummy variable taking a value 1 if the Russian companies are listed on any international stock exchange outside Russian Federation. The regressions results are derived from OLS with clustering at company level. 


\section{$\underline{\text { Figures }}$}

Figure 1: T\&D indexes, 2003-2007

There are four transparency \& disclosure indexes (T\&D) as proxies of corporate governance (CG) provided by Standard \& Poor year-to-year studies between 2003-2007. T\&D overall measures general implementation of CG code, T\&D financial \& operational information defines openness and availability of accounting data, employed standards, consistency with regulations, explanation and description of the firm and its market position, etc. T\&D ownership demonstrates the data availability on the ownership structure. T\&D board \& shareholders shows the disclosure of the management structure. T\&D measured in percentages with maximum $100 \%$ where higher score means better $T \& D$ within company. The same $T \& D$ indexes, but over shorter period of time were implied by Black et al., 2006.

T\&D Ownership structure and shareholders rights

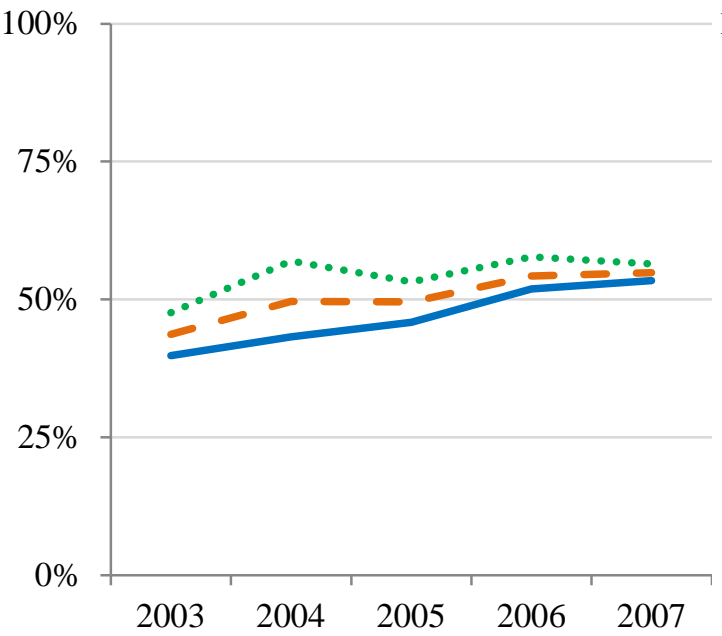

T\&D Financial and operational information

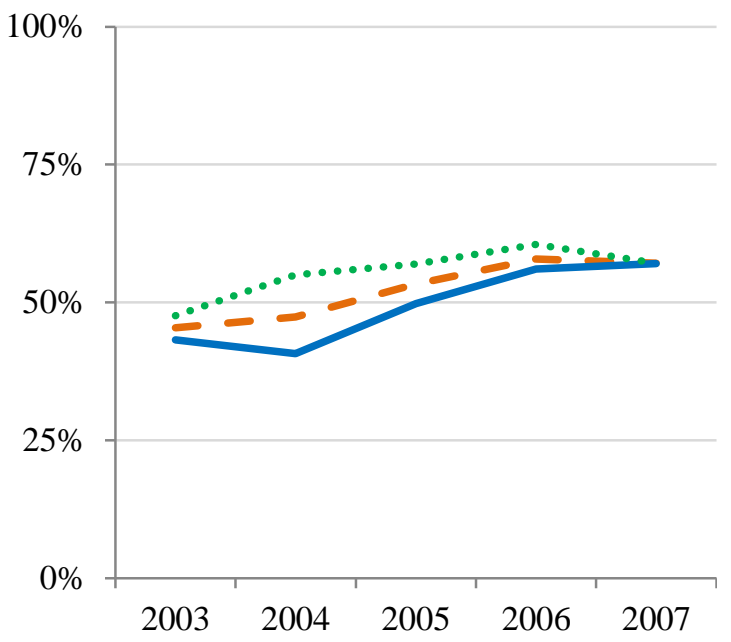

T\&D Board and management structure and process

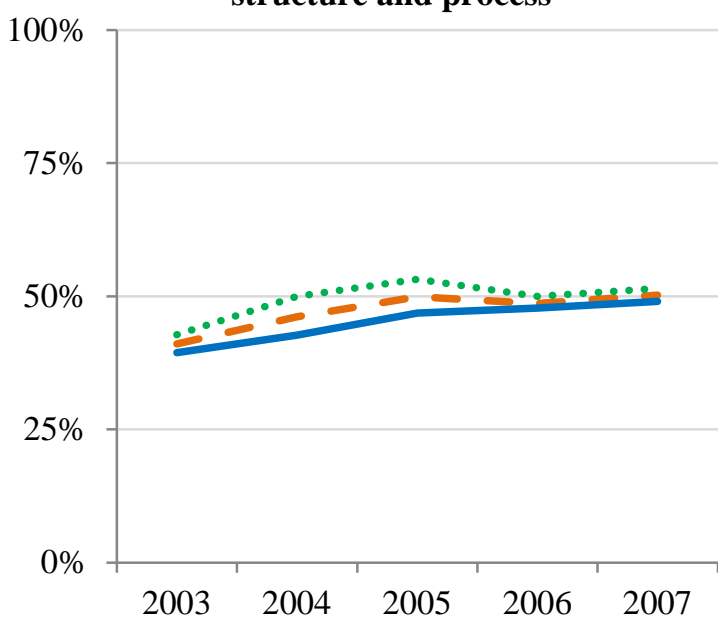

T\&D Overall score

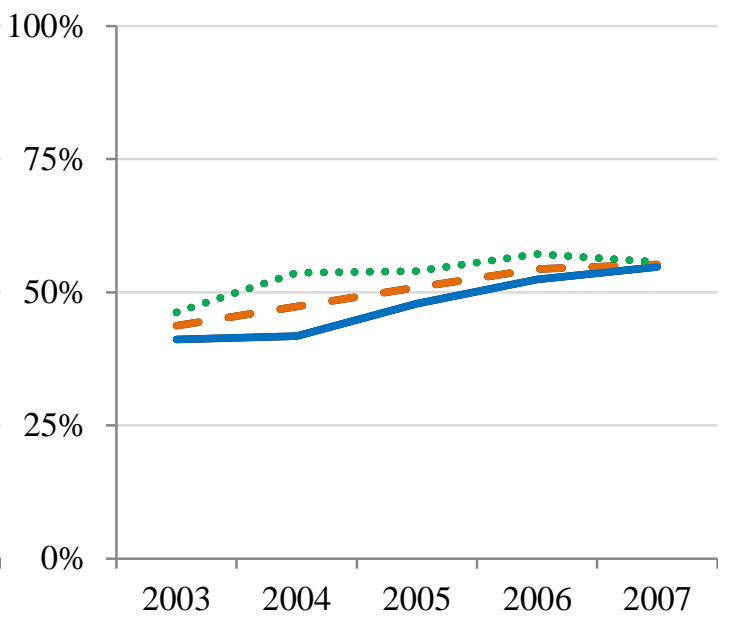

- $\quad$ All sectors firms (energy \& non-energy)

Energy firms

" * - " . Non-energy firms 


\section{Appendix 1: Construction of T\&D indices 2003-2007 by S\&P}

The survey was conducted by the Standard \& Poor's (S\&P in short). It uses only publicly available information, thus emphasizing that, a company's transparency score should not be compared with its corporate governance score (CGS), or otherwise interpreted as a measure of governance standards. A CGS is our assessment of a company's corporate governance practices, which is not limited to information disclosure. In addition, these scores are assigned on the basis of an in-depth, interactive analytical process involving both public and non-public data.

\section{Number of companies included}

The latest 2007 study covers 80 largest public Russian companies with the most liquid stock. In 2006, S\&P analysed 70 companies. In 2005, 2004 and 2003 years the survey covered 54, 50 and 45 respectively.

\section{Criteria to select companies}

S\&P used two criteria to select the companies in the study: size and liquidity. As a rule, the liquidity of stocks positively depends on the size of the company, but there are exceptions, especially in cases of minor free-float. There are more than 300 public companies in Russia, and this sample may not be representative of all Russian public companies. As the larger companies tend to be more transparent than smaller ones, our sampling method is likely to cause an upward bias in assessing transparency of the entire population of public Russian companies. On the other hand, as the companies included in the survey account for about $80 \%$ of the cumulative capitalization of the Russian stock market, they represent the major part of the Russian economy in terms of assets and operations.

\section{S\&P's industries covered}

S\&P covers such industries as Telecommunications, metallurgy, utilities, oil-and-gas, banking, food, consumer and retails and IT engineering. In our analysis we classify these industries between energy and non-energy sectors and compare those with all-industries together. We apply Classification Standard (GICS) codes to classify firms in our sample. As we focus on energy industry, GICS allowed us to identify 9 main energy subsectors within the energy industry. We have selected utilities and oil-and-gas producers as the two largest ones consisting $64 \%$ of overall energy sector. We provide the fill firms sample in the Appendix 2.

\section{Components of T\&D indices and scoring}

$\mathrm{S} \& \mathrm{P}$ have introduced six components and grouped these in three T\&D scores. Subject to these clarifications, these are:

- T\&D ownership structure and shareholders rights

- T\&D financial and operational information

- T\&D board and management structure

The first T\&D consists of "ownership structure" and "shareholder rights" which represented by 17 questions each. The next T\&D is a composition of "financial information" and "operational information" disclosure. These are based on 31 and 16 questions respectively. The last third T\&D scoring consists of "board and management information" and "board and management remuneration", based on 16 and 8 questions. S\&P then calculated the scores for each answer in every section and provided with the total scores for each T\&D for the observed companies. The score has a range of minimum $0 \%$ and maxim $100 \%$ for the best transparency \& disclosure. S\&P does not explain the methodology behind the percentage score as it uses specially designed method. We show the T\&D scorings for each observed company in Appendix 2.

\section{Component 1. Ownership structure}

\section{Disclosure of:}

1. The number and par value of issued ordinary shares.

2. The number and par value of issued other types of shares disclosed.

3 . The number and par value of authorized but unissued shares of all types.

4. The identity of the largest shareholder.

5. The identity of holders of all large stakes (blocking: > 25\%; controlling:> 50\%). 
6. The identity of shareholders holding at least $25 \%$ of voting shares in total.

7. The identity of shareholders holding at least $50 \%$ of voting shares in total.

8 . The identity of shareholders holding at least $75 \%$ of voting shares in total.

9. The number and identity of each shareholder holding more than $10 \%$.

10. The indication that management is not aware of the existence of anystake exceeding $5 \%$ in except for those that are reported.

11. Shareholding in the company by individual senior managers.

12. Shareholding in the company by individual directors.

13 . The description of share classes.

14. A review of shareholders by type.

15. The percentage of cross-ownership.

16. Information about listings on exchanges.

17. Information about indirect ownership (e.g., convertible instruments).

\section{Component 2. Shareholder rights}

\section{Disclosure of:}

18. Corporate governance charter or corporate governance guidelines.

19. Evidence of existence of a code of business conduct and ethics.

20 . The contents of the code of business conduct and ethics.

21. Articles of association (including changes).

22. Voting rights for each voting or nonvoting share.

23. The way that shareholders nominate directors to the board.

24. The way that shareholders convene an extraordinary general meeting (EGM).

25. Procedure for initiating inquiries with the board.

26. Procedure for putting forward proposals at shareholders meetings.

27. Formalized dividend policy.

28. Announcement of recommended dividends before the record date.

29. Review of the last shareholders meeting.

30. Full general shareholder meeting (GSM) minutes.

31 . Calendar of important shareholder future dates.

32. GSM materials published on the Web site.

33 .Detailed press releases covering last corporate events.

34. Policy on information disclosure.

\section{Component 3. Financial information}

\section{Disclosure of:}

35. The company's accounting policy.

36. The accounting standards it uses for its accounts.

37. Accounts according to local standards.

38. Annual financial statements according to an internationally recognized accounting standard (IFRS/U.S. GAAP).

39. Notes to annual financial statements according to IFRS/U.S. GAAP.

40. Independent auditor's report on annual financial statements according to IFRS/U.S. GAAP.

41. Unqualified (clean) audit opinion on annual financial statements according to IFRS/U.S. GAAP.

42. Audited IFRS/U.S. GAAP financial statements published before the end of April.

43. Unaudited IFRS/U.S. GAAP financial statements published before the end of April.

44. Audited IFRS/U.S. GAAP financial statements published before annual general meeting.

45. Unaudited IFRS/U.S. GAAP financial statements published before the end of June.

46. Disclosure of related-party transactions (RPTs): sales to/purchases from payables to/receivables from related parties.

47. Indication that RPTs are made on market or nonmarket terms.

48. Exact terms of RPTs.

49. Interim (quarterly or semi-annual) financial statements according to an internationally recognized accounting standard (IFRS/U.S. GAAP).

50. Notes to these financial statements.

51. Whether these financial statements are audited or at least reviewed. 
52. Consolidated financial statements according to the local standards.

53. Methods of asset valuation.

54. A list of affiliates in which the company holds a minority stake.

55. The ownership structure of affiliates.

56. A basic earnings forecast of any kind.

57. A detailed earnings forecast.

58. Segment analysis (results broken down by business line).

59. Revenue structure (detailed breakdown).

60. Cost structure (high degree of detail).

61 . The name of the auditing firm.

62. Whether the audit firm is a top-tier auditor.

63. Auditor rotation policy.

64. How much the company pays in audit fees to the auditor.

65 . Whether auditor renders non-audit services.

66. Non-audit fees paid to the auditor.

\section{Component 4. Operational information}

\section{Disclosure of:}

67. Details of the type of business the company is in.

68. Details of the products or services the company produces or provides.

69. Output in physical terms.

70. A description of functional relationships between key operating units within the group.

71. Industry indicators that allow comparison with peers.

72. Other financial indicators.

73. Characteristics of fixed assets employed (including licenses).

74. Efficiency indicators.

75. A discussion of corporate strategy.

76. Any plans for investment in the coming years.

77. Detailed information about investment plans in the coming year.

78. An output forecast of any kind.

79. An overview of trends in its industry; regulatory environment with regards to industry.

80 . The market share for any or all of the company's businesses.

81. Social reporting (e.g., Global Reporting Initiative).

82. Overview of compliance with environmental law.

83. Principles of corporate citizenship.

\section{Component 5. Board and management information}

\section{Disclosure of:}

84. The list of board members (names).

85. Details about the current employment and position of directors.

86. Other details: previous employment and positions, education, etc.

87. When each director joined the board.

88. The name of the chairman.

89. Details about role of the board of directors at the company.

90. A list of matters reserved for the board.

91. A list of board committees.

92. Names of all members of each existing committee.

93. The bylaws on other internal audit functions besides the audit committee.

94. Information about the ratio of in absentia and in person board meetings.

95. Attendance record for board meetings.

96. The list of senior managers not on the board of directors.

97. The backgrounds of senior managers.

98. The non-financial details of the CEO's contract.

99. The number of shares held in other affiliated companies by managers.

100. Policy on assessment of board of directors and on training provided to them. 
Component 6. Board and management remuneration

Disclosure of:

101. The decision-making process for directors' pay.

102. The specifics of directors' pay, including the salary levels.

103. The form of directors' salaries, such as whether they are in cash or shares.

104. The specifics of performance-related pay for directors.

105. The decision-making process for determining managerial (not board) pay.

106. The specifics of managers' (not board) pay, such as salary levels and bonuses.

107. The form of managers' (not board) pay.

108. The specifics of performance-related pay for managers. 
Table A1: T\&D scores by companies, 2003 - 2007

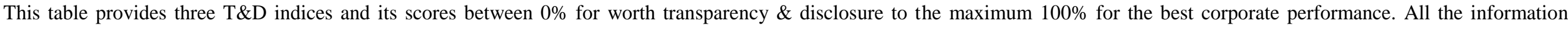

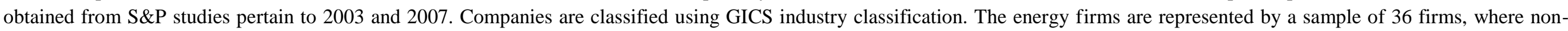

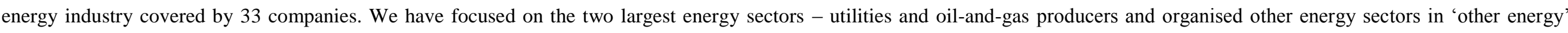

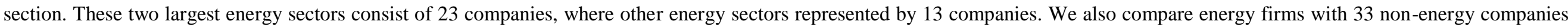
which cover such industries polled together as telecommunications, metallurgy, utilities, oil-and-gas, banking, food, consumer and retails and IT engineering.

\begin{tabular}{|c|c|c|c|c|c|c|}
\hline \multirow{2}{*}{$\begin{array}{c}\text { Companies sectoral } \\
\text { breakdown }\end{array}$} & & \multicolumn{5}{|c|}{$\begin{array}{c}\text { Ownership structure and } \\
\text { shareholders rights, \% }\end{array}$} \\
\hline & & 2003 & 2004 & 2005 & 2006 & 2007 \\
\hline $\begin{array}{l}\text { All sectors } \\
\text { ( } 69 \text { companies; energy \& } \\
\text { non-energy) }\end{array}$ & $\begin{array}{l}\text { Mean } \\
\text { St Dev. }\end{array}$ & $\begin{array}{l}0.44 \\
0.20\end{array}$ & $\begin{array}{l}0.50 \\
0.20\end{array}$ & $\begin{array}{l}0.50 \\
0.19\end{array}$ & $\begin{array}{l}0.54 \\
0.16\end{array}$ & $\begin{array}{l}0.55 \\
0.16\end{array}$ \\
\hline $\begin{array}{l}\text { 1. Energy sector } \\
\text { (36 companies) }\end{array}$ & $\begin{array}{l}\text { Mean } \\
\text { St Dev. }\end{array}$ & $\begin{array}{l}0.40 \\
0.10 \\
\end{array}$ & $\begin{array}{l}0.43 \\
0.18 \\
\end{array}$ & $\begin{array}{l}0.46 \\
0.16 \\
\end{array}$ & $\begin{array}{l}0.52 \\
0.16 \\
\end{array}$ & $\begin{array}{l}0.53 \\
0.15 \\
\end{array}$ \\
\hline $\begin{array}{l}\text { Energy sector - Utilities } \\
(10 \text { companies })\end{array}$ & $\begin{array}{l}\text { Mean } \\
\text { St Dev. }\end{array}$ & $\begin{array}{l}0.37 \\
0.09 \\
\end{array}$ & $\begin{array}{l}0.45 \\
0.14 \\
\end{array}$ & $\begin{array}{l}0.43 \\
0.13 \\
\end{array}$ & $\begin{array}{l}0.50 \\
0.09 \\
\end{array}$ & $\begin{array}{l}0.53 \\
0.11 \\
\end{array}$ \\
\hline $\begin{array}{l}\text { 1.2. Energy sector - Oil- } \\
\text { and-gas producers } \\
\text { (13 companies) }\end{array}$ & $\begin{array}{l}\text { Mean } \\
\text { St Dev. }\end{array}$ & $\begin{array}{l}0.41 \\
0.09\end{array}$ & $\begin{array}{l}0.43 \\
0.23\end{array}$ & $\begin{array}{l}0.47 \\
0.17\end{array}$ & $\begin{array}{l}0.50 \\
0.21\end{array}$ & $\begin{array}{l}0.49 \\
0.20\end{array}$ \\
\hline $\begin{array}{l}\text { 1.3. Energy sector - other } \\
\text { (13 companies) }\end{array}$ & $\begin{array}{l}\text { Mean } \\
\text { St Dev. }\end{array}$ & $\begin{array}{l}0.43 \\
0.16 \\
\end{array}$ & $\begin{array}{l}0.41 \\
0.18 \\
\end{array}$ & $\begin{array}{l}0.47 \\
0.22 \\
\end{array}$ & $\begin{array}{l}0.55 \\
0.15 \\
\end{array}$ & $\begin{array}{l}0.58 \\
0.10 \\
\end{array}$ \\
\hline $\begin{array}{l}\text { 2. Non-energy sector } \\
\text { ( } 33 \text { companies) }\end{array}$ & $\begin{array}{l}\text { Mean } \\
\text { St Dev. }\end{array}$ & $\begin{array}{l}0.48 \\
0.26\end{array}$ & $\begin{array}{l}0.57 \\
0.20\end{array}$ & $\begin{array}{l}0.53 \\
0.21\end{array}$ & $\begin{array}{l}0.58 \\
0.18 \\
\end{array}$ & $\begin{array}{l}0.56 \\
0.18 \\
\end{array}$ \\
\hline
\end{tabular}

\begin{tabular}{|c|c|c|c|c|}
\hline \multicolumn{5}{|c|}{$\begin{array}{c}\text { Financial and operational } \\
\text { information, } \%\end{array}$} \\
\hline 2003 & 2004 & 2005 & 2006 & 2007 \\
\hline 0.45 & 0.47 & 0.53 & 0.58 & 0.57 \\
\hline 0.19 & 0.22 & 0.20 & 0.17 & 0.15 \\
\hline 0.43 & 0.41 & 0.50 & 0.56 & 0.57 \\
\hline 0.13 & 0.21 & 0.19 & 0.19 & 0.16 \\
\hline 0.38 & 0.39 & 0.43 & 0.46 & 0.50 \\
\hline 0.14 & 0.18 & 0.13 & 0.16 & 0.13 \\
\hline 0.47 & 0.40 & 0.50 & 0.58 & 0.58 \\
\hline 0.12 & 0.27 & 0.21 & 0.21 & 0.16 \\
\hline 0.47 & 0.44 & 0.56 & 0.64 & 0.62 \\
\hline 0.15 & 0.19 & 0.22 & 0.16 & 0.16 \\
\hline 0.48 & 0.55 & 0.57 & 0.61 & 0.57 \\
\hline 0.24 & 0.22 & 0.22 & 0.15 & 0.14 \\
\hline
\end{tabular}

\begin{tabular}{|c|c|c|c|c|}
\hline \multicolumn{5}{|c|}{$\begin{array}{l}\text { Board and management } \\
\text { structure and process, \% }\end{array}$} \\
\hline 2003 & 2004 & 2005 & 2006 & 2007 \\
\hline 0.41 & 0.46 & 0.50 & 0.49 & 0.50 \\
\hline 0.17 & 0.17 & 0.16 & 0.14 & 0.14 \\
\hline 0.39 & 0.43 & 0.47 & 0.48 & 0.49 \\
\hline 0.10 & 0.17 & 0.16 & 0.13 & 0.12 \\
\hline 0.36 & 0.44 & 0.44 & 0.53 & 0.50 \\
\hline 0.09 & 0.14 & 0.12 & 0.11 & 0.13 \\
\hline 0.40 & 0.43 & 0.52 & 0.43 & 0.45 \\
\hline 0.12 & 0.25 & 0.16 & 0.16 & 0.14 \\
\hline 0.44 & 0.42 & 0.44 & 0.48 & 0.53 \\
\hline 0.09 & 0.09 & 0.20 & 0.09 & 0.09 \\
\hline 0.43 & 0.50 & 0.53 & 0.50 & 0.51 \\
\hline 0.22 & 0.16 & 0.15 & 0.16 & 0.16 \\
\hline
\end{tabular}

\begin{tabular}{|c|c|c|c|c|}
\hline \multicolumn{5}{|c|}{ Overall T\&D Score, \% } \\
\hline 2003 & 2004 & 2005 & 2006 & 2007 \\
\hline 0.44 & 0.47 & 0.51 & 0.54 & 0.55 \\
\hline 0.17 & 0.18 & 0.19 & 0.14 & 0.13 \\
\hline 0.41 & 0.42 & 0.48 & 0.52 & 0.55 \\
\hline 0.09 & 0.18 & 0.17 & 0.14 & 0.13 \\
\hline 0.37 & 0.42 & 0.43 & 0.49 & 0.51 \\
\hline 0.09 & 0.15 & 0.13 & 0.11 & 0.11 \\
\hline 0.43 & 0.41 & 0.50 & 0.52 & 0.54 \\
\hline 0.08 & 0.24 & 0.18 & 0.18 & 0.17 \\
\hline 0.45 & 0.43 & 0.50 & 0.57 & 0.59 \\
\hline 0.13 & 0.15 & 0.21 & 0.13 & 0.10 \\
\hline 0.46 & 0.54 & 0.54 & 0.57 & 0.56 \\
\hline 0.23 & 0.18 & 0.20 & 0.14 & 0.13 \\
\hline
\end{tabular}

Source: S\&P Reports (various) 